\title{
ANALISIS STRATEGI PENGEMBANGAN PINJAMAN DANA PERKUATAN MODAL DALAM PENINGKATAN PEREKONOMIAN UKM PADA UPTD PERKUATAN MODAL KUMKM PROVINSI LAMPUNG \\ (Studi di Dinas Koperasi, UMKM Perindustrian dan Perdagangan Provinsi Lampung)
}

\author{
Oleh: \\ Suradi $^{1}$ \\ Sukoyo ${ }^{2}$ \\ Jurusan Administrasi Bisnis, Universitas Tulang Bawang Lampung \\ e-Mail: suradi0469@gmail.com
}

\begin{abstract}
ABSTRAK
Berdasarkan tugas dan fungsi dinas koperasi UMKM perindustrian dan perdagangan dalambidang koperasi dan UKM salah satunya yaitu pelaksanaan kebijakan teknis, pemberianbimbingan serta fasilitasi pembiayaan bagi UKM di provinsi lampung. Untuk mendukungprogram pengembangan UKM khususnya bidang pembiayaan, maka pemerintah provinsilampung melalui dinas koperasi UMKM perindustrian dan perdagangan provinsi lampungsejak tahun anggaran 2003 sampai dengan 2006 telah melaksanakan dana APBD provinsilampung sebagai dana perkuatan modal bagi UKM sebesar Rp 12 milyar.

Sejak tahun 2007 pemerintah provinsi lampung berdasarkan peraturan gubernur lampungNomor 14 tahun 2008 tentang pembentukan organisasi dan tata Kerja Unit PelaksanaanTeknis Dinas (UPTD) pada dinas Daerah Provinsi Lampung maka sejak dikeluarkannyaperaturan gubernur tersebut pengelolaan dana perkuatan modal UKM dikelola oleh UnitPelaksanaan Teknis Daerah Perkuatan Modal Koperasi Usaha Mikro Kecil dan Menengah(UPTD PM-KUMKM) Provinsi lampung, Yang berkedudukan dibawah Dinas Koperasi UMKMPerindustrian dan Peradagangan Provinsi Lampung merupakan salah satu domain organisasipemerintah yang memiliki peran strategis didalam pemberdayaan UKM di Provinsi LampungDengan terbentuknya UPTD PMKUMKM yang mempunyai tugas pokok melaksanakanpemberdayaan UKM melalui program perkuatan modal usaha dalam rangka Peningkatanperan UKM dalam perekonomian daerah dan fungsi (1) Pemberian layanan perkuatan modal usaha kepada UKM baik usaha perorangan maupun kelompok atau Lembaga KeuanganMikro (LKM), (2) Peningkatan produktivitas dan skala usaha UKM, (3) peningkatan mutuSumber Daya Manusia UKM penerima dan perkuatan modal usaha, (4) Peningkatan aktivitasperekonomian daerah sektor riel dan pendapatan daerah, Maka pengelolaan danaperkuatan modal UKM menjadi kewenangan UPTD PM-KUMKM.

Berdasarkan kesimpulan yang telah dikemukakan diatas, Maka penulis mengajukan saransebagai berikut (1) Hendaknya UPTD perkuatan modal PM-KUMKM Provinsi Lampungmenambah sosialisasi terhadap UKM yang ada di lampung (2) Hendaknya UPTD perkuatan modal PMKUMKM Provinsi Lampung menambah batas maksimal pinjaman sampai Rp 100juta . Karena saat ini baru batas maksimal Rp 50 juta.
\end{abstract}

Kata kunci: dana perkuatan modal, perekonomian UKM, dinas KUMKM provinsi Lampung 


\section{PENDAHULUAN}

\section{A. Latar Belakang}

Menghadapi era globalisasi dan AFTA, serta fase APEC sampai pada tahun2020, selain merupakan tantangan juga merupakan peluang yang sangat strategis untukmemberdayakan Usaha Kecil dan Menengah (UKM). Adanya kemauan politik yangtinggi dari pemerintah juga merupakan peluang yang sangat besar untukmenumbuhkembangkan ekonomi rakyat, khususnya UKM. Melalui paradigma barupembangunan diharapkan tidak lagi terjadi pemusatan aset ekonomi produktif padasegelintir orang atau golongan, melainkan justru sebaliknya memperluas aset produktifditangan rakyat. Hal ini sebagai bukti bahwa keberadaan UKM sebagai pelaku ekonomirakyat mempunyai kedudukan yang sangat penting dalam rangka untuk meningkatkandan menjaga kesetabilan perekonomian regional maupun nasional.

Peranan UKM dalam menopang perekonomian nasional maupun regional daritahun ke tahun baik eksistensi, ketangguhan maupun kontribusinya terus meningkat.Keberhasilan UKM ini dikarenakan, pertama, UKM tidak memiliki utang luar negeridan tidak banyak utang ke perbankan. Kedua, sektor-sektor kegiatan UKM, sepertipertanian, perdagangan, industri rumah tangga, dan lain-lainnya tidak bergantungsumber bahan baku dari luar negeri. UKM menggunakan bahan baku lokal. Ketiga,walaupun belum semuanya, UKM berorientasi ekspor. Dapat dikatakan UKMmerupakan soko guru perekonomian nasional. SumbanganUKM terhadap produkdomestic bruto (PDB) mencapai $54 \%-57 \%$, dan kontribusinyaterhadappenyerapan tenaga kerja sekitar 96\% (KementerianKoperasi dan UKM, 2012).
Usaha Kecil dan Menengah (UKM) memiliki peranan penting dalam perekonomian di Indonesia UKM memili proporsi sebesar $99.99 \%$ dari totalkeseluruhan pelaku usaha di Indonesia atau sebanyak 52,76 juta unit (BPS 2011) Data Badan Pusat Statistik (BPS) tahun 2011 tersebut juga menunjukkan bahwa UKMterbukti berkontribusi sebesar 56.92\% dari total Produk Domestik Bruto (PDB) Indonesia atau setara dengan Rp1.213,25 Triliun. Selain itu, UKM memilikikemampuanmenyeraptenaga kerja (menyerap 97,3\% dari total angkatan kerja yang bekerja) dan memiliki jumlah yang besar dari total unit usaha di Indonesia sertakontribusi yang cukup besar terhadap investasi di Indonesia yaitu sebesar $\mathrm{Rp}$ 222,74 Triliun atau $51,80 \%$ daritotal investasipada tahun2011 (Bank Indonesia, 2011).

UKM merupakan kegiatan usaha yang mampu memperluas lapangan kerja,memberikanpelayanan ekonomi secara luas kepada masyarakat, berperan dalam prosespemerataan dan peningkatan pendapatan masyarakat, mendorong pertumbuhanekonomi, dan berperandalam mewujudkan stabilitas nasional (Iman dan Adi, 2009)

Mengingat besarnya peran UKM tersebut, maka pemerintah melalui instansi terkaitterutamaKementerian Koperasi dan UKM telah meluncurkan berbagai programbantuan.Kebijakan

pemerintahuntuk mendorong usaha kecil dan menengah cukupserius.Undang-Undang No 20 Tahun 2008 tentang Usaha Mikro, Kecil dan Menengah menegaskanbahwa, usaha ini perlu diselenggarakan secara menyeluruh, optimal, dan berkesinambunganmelaluipengembanganikl im yang kondusif, pemberian kesempatanberusaha,dukungan,perlindunga n,dan pengembangan usaha seluas-luasnya 
(Haryadi,2010). Usaha mikro merupakan kelompok pelaku usaha terbesar (9676) di Indonesia dengan karakteristik berpenghasilan rendah, bergerak di sektor informal dan sebagian besar termasuk dalam kelompok keluarga miskin. Bahkan dalam sebagian besar kasus, kelompok usaha mikro masih belum dapat memenuhi kebutuhan dasar untuk hidup, seperti: gizi, pendidikan, kesehatan dan lain-lain. Usaha mikro memiliki karakteristik yang unik dan belum tentu dapat diberdayakan socara optimal melalui mekanisme pasar yang bersaing untuk itu, pemberdaya usaha mikro perlu ditetapkan sebagai suatu strategi yang tersendiri, melalui pengembangan pranata kelembagaan usaha mikro, pengembangan lembaga keuangan mikro dan mendorong pengembangan industri pedesaan (Kementerian Koperasi dan UKM, 2012).

Salah satu kendala dalam perkembangan usaha mikro adalah keterbatasan modal yang dimiliki dan sulitnya mengakses sumber permodalan, Mengutip laporan BPS, Dibyo Prabowo (2011:25) menegaskan bahwa 35,10\% UKM menyatakan kesulitan permodalan kemudian diikuti oleh kepastian pasar 25,9\% dan kesulitan bahan baku1 5,4\%.Dalam kondisi yang demikian kelompok ini akan sangat sulit keluar dari permasalahan yang biasanya sudah berjalan lama tersebut, kecuali bila ada intervensi dari pihak lain, Kim (1994:45) lebih lanjut mengatakan bahwa intervensi untuk memutus rantai permasalah ini dapat saja dilakukan jika ada komitmen yang kuat dari pemerintah dan masyarakat melalui pemberian pinjaman modal. Hal inilahyang menjadi dasar pemikiran pemerintah untuk melaksanakan perkuatan di bidang permodalan. Belum terlihatnya pengaruh nyata dari intervensi pemerintah tersebut diduga dikarenakan sangat kecilnya danadana pemerintah yang disalurkan dibandingkan dengan besarnya jumlah
UKM yang membutuhkannya, Di Provinsi Lampung mempunyai potensi industri yang cukup tinggi, sektor industri mempunyai kontribusi terbesar kedua setelah sektor perdagangan dan jasa dalam perolehan produk domestik regional bruto (PDB). Pada tahun 2011 konstribusi masing-masingmasing sektor usaha tersebut adalah sebagai berikut : Perdagangan dan jasa sebesar $29,86 \%$, industri pengolahan sebesar $24,52 \%$, dan sektor bangunan sebesar $19,27 \%$, Hal tersebutmenggambarkanbahwa aktivitas ekonomi masyarakat di Provinsi Lampung didominasi oleh sektor perdagangan dan jasa, sektor industri pengolahan dan sektor bangunan (Dinas Kop.UMKM dan Indag Prov.Lampung).

Jumlah UKM di Provinsi Lampung tiap tahunnya mengalami kenaikan, sehingga hal tersebut menunjukkan adanya pertumbuhan ekonomi yang produktif, karena adanya pertumbuhan dan iklim UKM yang membaik dan kondusif. Kenyataan menunjukkan bahwa pada saat terjadi krisis ekonomi, UKM lebih resisten dibanding perusahaan-perusahaan yang lebih besar. Hal inilah yang akan terus dijaga dan ditingkatkan melalui rencana fasilitasi permodalan yang mampu mengembalikan koperasi sebagai soko guru perekonomian masyarakat yang tidak hanya aktif namun juga benar sehat sehingga mampu menjaga pertumbuhan ekonomi terutama dari pengembangan UKM.

Berdasarkan tugas dan fungsi Dinas Koperasi, UKM Perindustrian dan Perdagangan dalam bidang Koperasi dan UKM salah satunya yaitu pelaksanaan kebijakan teknis, pemberian bimbingan serta fasilitasi pembiayaan bagi UKM diProvinsi Lampung. Untuk mendukung program pengembangan UKM khususnyabidang pembiayaan, maka Pemerintah Provinsi Lampung melalui Dinas Koperasi, UMKM Perindustrian dan Perdagangan Provinsi 
Lampung sejak Tahun Anggaran 2003sampai dengan 2006 telah mengalokasikan dana APBD Provinsi Lampung sebagai dana perkuatan modal bagi UKM sebesar Rp. 12 miliar yang disalurkan kepada 807 UKM di 14 Kabupaten/Kota, dengan perincian sebagai berikut, tahun anggaran 2003 sebesar Rp 4,550.000.000,- yang disalurkan kepada 232 UKM, tahun anggaran 2004 sebesar Rp. 5,450.000.000,- disalurkan kepada 342 UKM dan tahun anggaran 2006 sebesar Rp. 2.000.000.000,- yang disalurkan kepada 233 UKM. Pengunaan jasa pinjaman dana perkautan modal UKM sebesar 6\% per tahun secara flat dengan jangka waktu pinjaman selama 2 (dua) tahun. (UPTD PM-KUMKM Provinsi Lampung, 2012).

Dalam rangka untuk meningkatkan kinerja pengelolaan dana perkuatan modal UKM, sejak tahun 2007 Pemerintah Provinsi Lampung berdasarkan PeraturanGubernur Lampung Nomor 14 tahun 2008 tentang Pembentukan, Organisasi dan TataKerja Unit Pelaksana Teknis Dinas (UPTD) pada Dinas Daerah Provinsi Lampung, maka sejak dikeluarkanya Peraturan Gubernur tersebut pengelolaan dana perkuatan modal UKM dikelola oleh Unit Pelaksana Teknis Daerah Perkuatan Modal KoperasiUsaha Mikro Kecil dan Menengah (UPTD PMKUMKM) Provinsi Lampung, yang berkedudukan dibawah Dinas Koperasi, UMKM, Perindustrian dan Perdagangan Provinsi Lampung merupakan salah satu domain organisasi pemerintah yang memiliki peran strategis didalam pemberdayaan UKM di Provinsi Lampung. UPTD PM-KUMKM adalah merupakan Satuan Unit Kerja pada Satuan Kerja Perangkat Daerah(SKPD) yang menerapkan Pola Pengelolaan Keuangan Badan Layanan Umum Daerah (PPK-BLUD) yang dibentuk untuk memberikan pelayanan kepada masyarakat berupa penyaluran dana perkuatan modal UKM.

Sejak dibentuknya UPTD PMKUMKM yang mempunyai tugas pokokMelaksanakan pemberdayaan UKM, melalui Program Perkuatan Modal Usaha dalamrangka Peningkatan peran UKM dalam perekonomian daerah dan fungsi (1) Pemberianlayanan perkuatan modal usaha kepada UKM baik usaha perorangan maupun kelompok atau Lembaga Keuangan Mikro (LKM), (2) Peningkatan produktivitas dan skala usahaUKM, (3) Peningkatan mutu Sumber Daya Manusia UKM penerima dana perkuatan modal usaha,(3)

Peningkatanaktivitasperekonomiandaerahse ktor riel dan pendapatandaerah, maka pengelolaandana perkuatan modal UKM menjadi kewenangan UPTDPM-KUMKM. Kinerja pengelolaan dana perkuatan modal UKM berdasarkan data padaoleh UPTD PM-KUMKM Provinsi Lampung dapat dilihat bahwa pengelolaan dana perkuatan modal UKM sejak tahun2008 sampai dengan 2012 mengalami peningkatanyaitu omset penyaluran per 30 November 2012 mancapai Rp.32.265.000.000,- dengan jumlah UKM peminjam sebanyak 1.720 UKM, sedangkan pengembalian pinjaman dana perkuatan modal UKM kepada UPTD PM-KUMKM yang disetorkan Bank Lampung telah mencapai Rp. 26.855.000.000,- dan jumlah UKM yang telahmelunasi pinjaman sebanyak 764 UKM,

Walaupun tingkat pengembalian angsuran tersebut masih sangat rendah apabila dibandingkan dengan perbankan akan tetapi setiap tahun UKM banyak yangmengajukan usulan proposal dansa bergulir tersebut kepada UPTD PMKUMKM, Artinya program perkuatan permodalan yang berupa dana perkuatan modal UKM tetapdiminati dan dilaksanakan. Upaya menyeleksi unit usaha UKM yang 
layak mendapatbantuan dana perkuatan modal dilakukan oleh tim dari UPTD PMKUMKM melalui proses analisa kelayakan dengan berbagai persyaratan yang telah ditentukan sebelumnya. Berdasarkan petunjuk teknis pengelolaan dana perkuatan modal ini, makaUKM yang mendapat bantuan, tentunya unit usaha yang dipandang mampu meningkatkan usaha dan mampu mengembalikan angsuran, Namun rendahnya tingkat pengembalian angsuran menimbulkan pertanyaan yang perlu dikaji untuk dicarikan penyebab, kendala dan faktor-faktor yang mempengaruhi rendahnya tingkat pengembalian angsuran pinjaman dana perkuatan modal, Khusus untuk penyaluran pinjaman dana bergulir bagi UKM, Program perkuatan permodalan UKM tersebut dimaksudkan untuk meningkatkan kemampuan usaha UKM dalam rangka untuk meningkatkan perekonomian UKM, namun jika adanya data-data tunggakan di atas, maka bisa ditarik kesimpulan bahwa program bantuan modal tidak bisa bergulir secara lancar, Program ini mengalam ihambatan dan kendala dalam upaya mengembalikan angsuran secara rutin dan tepat waktu jatuh tempo angsuran,

Mengingat luasnya wilayah penyalurandanperkuatan modal bagi UKM yang mencakup 14 Kabupaten/Kota maka dalam penelitian ini, obyek penilitan adalah UKM peminjam yang berada di Kota Bandar Lampung, dengan melihat penjelasan di atas, dengan permasalahan yang dihadapi dalam penyaluran dan pemanfaatan dan perkuatan bagi UKM, maka dalam penelitian ini akan dibahas mengenai strategi pengembangan pinjaman dan perkuatan serta perkembangan usaha UKM, omzet penjualan, dan laba setelah mendapat pinjaman dana perkuatan dari UPTD PM-KUMKM.

\section{B. Tujuan dan Kegunaan Penelitian}

Tujuan yang ingin dicapai dalam penelitian ini adalah :

1. Untuk mengetahui perkembangan penyaluran dana perkuatan modal UKM olehUPTD PM-KUMKM,

2. Untuk mengetahui perkembangan usaha UKM penerima dana perkuatan modalUKM.

3. Untuk mengetahui tingkat pengembalian pinjaman dana perkuatan modal UKM.

4. Untuk mengetahui pelaksanaan pembinaan oleh UPTD PMKUMKM terhadap

5. UKM penerima dana.

\section{Hipotesis}

Berdasarkan rumusan masalah maka hipotesis yang dirumuskan sebagai berikut: "Jika strategi pengembangan pinjaman dana perkuatan modal tepat sasaran akan berpengaruh pada peningkatan perekonomian UKM".

\section{Kerangka Pemikiran}

Untuk mengarahkan penelitian agar sesuai dengan permasalahan dan tujuan yang ditetapkan, maka perlu disusun kerangka pemikiran dalam melaksanakan penelitian ini.

Penelitian ini lebih ditujukan untuk menganalisis strategi pengembangan pinjaman dana perkuatan modal UPTD PMKUMKM kepada UKM dengan melihat perkembangan usaha UKM antara sebelum dan setelah memperoleh dana perkuatan modal UKM.

Adapun kerangka berpikir disusun sebagai berikut:

Gambar.1 Kerangka Pemikiran Penelitian 


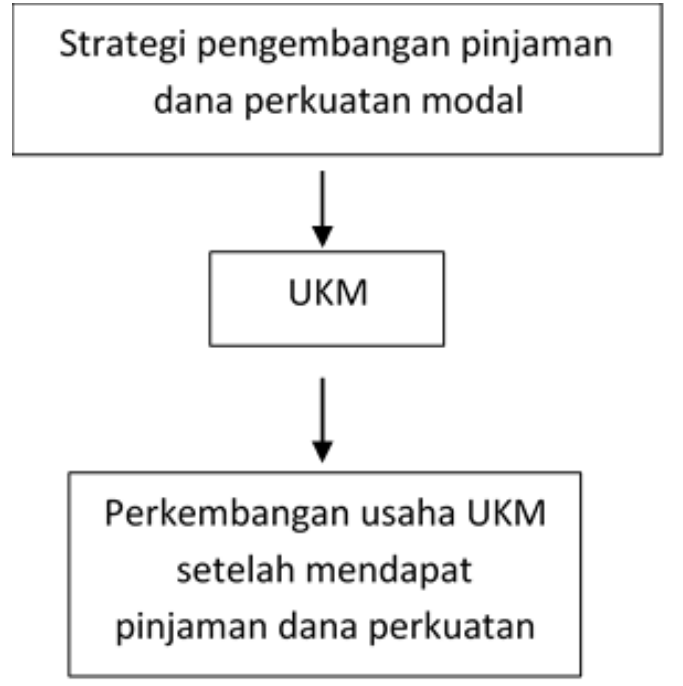

\section{METODOLOGI PENELITIAN}

\section{A. Tipe Penelitian}

Tipe penelitian yang digunakan adalah penclitian deskriptif (descriptiveresearch). Menurut Ronny Kountur (2003), penelitian deskriptif adalah jenis penelitianyang memberikan gambaran atau uraian atas suatu keadaan sejelas mungkin tanpa adaperlakuan terhadap obyek yang diteliti.

Bertolak dari berbagai pendapat tersebut di atas, maka dalam penelitian ini akanmenggunakan metode penelitian kualitatif, dimana kondisi suatu obyek bersifatalamiah, kemudian data dan informasi berdasarkan fakta-fakta yang tampak dan akandianalisis lebih lanjut oleh penulis dengan menggambarkan hasil-hasil temuandilapangan dengan sistematis secara langsung. Jenis penelitian deskriptif dipilih karenasesuai dengan tujuan-tujuan yang akan dicapai dalam penelitian ini yaitu untuk melihatstrategi pengembangan pinjaman dana perkuatan modal dalam peningkatanperekonomian UKM.

\section{B. Metode Penelitian}

Metode penelitian yang di gunakan metode survey. Menurut MasriSingarimbun dan Sofyan Effendy (2002), penelitian survey adalah penelitian yangmengambil sampel dari suatu populasi dan menggunakan kuesioner sebagai alatpengumpulan data yang pokok.

\section{HASIL PENELITIAN DAN PEMBAHASAN}

\section{A. Hasil Penelitian}

Pemerintah Provinsi Lampung dalam rangka untuk menunjang programpemberdayaan Koperasi Usaha Mikro Kecil dan Menengah (KUMKM) melaluiperkuatan modal usaha Koperasi dan UMKM merupakan salah satu strategi pemulihanekonomi yang dilakukan oleh Pemerintah Provinsi Lampung untuk mengantisipasiterjadinya stagnasi pertumbuhan ekonomi daerah sebagai dampak krisis ekonominasional tahun 1998. Penyelenggarakan kegiatan perkuatan modal usaha KUMKMdilakukan sejak tahun 2003. Pemerintah Provinsi Lampung telah mengalokasikan danaAPBD untuk disalurkan kepada KUMKM sebagai dana bergulir perkuatan modal usaha. Total dana APBD Provinsi Lampung yang dialokasikan untuk perkuatan modal usaha KUMKM sebesar Rp.12 miliar dengan tahapan sebagai berikut (1) TA. 2003sebesar Rp. 4,55 miliar, (2) TA.2004 sebesar Rp. 5,45 miliar, dan (3) TA.2006 sebesarRp.2,0 miliar. Dana perkuatan modal usaha KUMKM tersebut dikelola oleh DinasKoperasi, UMKM, Perindustrian dan Perdagangan Provinsi Lampung yangdiperuntukkan bagi unit usaha KUMKM yang membutuhkan perkuatan dana/modal bagi pengembangan usahanya. Diharapkan upaya tersebut menghasilkan dampakpositif bagi penambahan pendapatan dan kesempatan kerja bagi KUMKM.

Untuk meningkatkan efektivitas pelaksanaan penyaluran dana perkuatan usahaKUMKM, setiap tahun dibentuk Tim Pelaksana Program Perkuatan Modal UsahaKUMKM Provinsi Lampung yang 
ditetapkan dengan keputusan Gubernur. Pada tahun2007 penyaluran dana perkuatan modal usaha KUMKM tersebut dihentikan untuk sementara berdasarkan surat Gubernur Lampung nomor 700/118/1V.05/2007 tanggal 30Januari 2007 hal ini dikarenakan adanya Peraturan Menteri Dalam Negeri Nomor 61Tahun 2007 tentang Pedoman Teknis Pengelolaan Keuangan Badan Layanan UmumDaerah (BLUD) pada Satuan Kerja Perangkat Daerah (SKPD) atau Unit Kerja SKPDharus mengacu pada Rencana Strategi Bisnis, Pola Tata Kelola dan Standar PelayananMinimal. Dengan adanya peraturan tersebut maka Pemerintah Provinsi Lampungmenerbitkan Peraturan Gubernur Lampung nomor 30 Tahun 2007 dengan dibentuknya Badan Layanan Umum Daerah Koperasi Usaha Mikro Kecil dan Menengah (BLUDKUMKM)pada Dinas Koperasi, UMKM Perindustrian dan Perdagangan ProvinsiLampung.

Setelah berjalan selama lima tahun, program pinjaman dana perkuatan modal usaha KUMKM menunjukkan hasil yang belum sepenuhnya sesuai dengan tujuan dan sasaran kegiatan. Hal itu terlihat dari data pengembalian angsuran yang masih sangat rendah. Adanya tunggakan menunjukkan bahwa penerima pinjaman dana bergulir belum berhasil mengembangkan usahanya sehingga tidak mampu membayar pinjaman dana. Ataukah ada sebab-sebab lain, sehingga mereka enggan mengangsur pinjamanyang telah diterima sebelumnya. Penelitian ini berusaha memperoleh masukan penyebab rendahnya tingkat pengembalian angsuran pinjaman dana perkuatan modal usaha KUMKM.

Berhasil tidaknya suatu program pembangunan yang digagas Pemerintah Daerah, pengukuran kinerjanya masih cenderung dibuat pada tataran input, proses dan Output, sedangkan outcome belum sepenuhnya diperhatikan (Muhammad,
2008). Seperti halnya kegiatan pinjaman dana perkuatan modal usaha KUMKM belum memperhatikan hasil akhir yang diperoleh setelah kegiatan penyaluran dana dilakukan. Hal ini mungkin terjadi karena masih terdapat kesulitan untuk menentukan indikator Outcome, benefit dan impak. Disamping itu, pengukuran terhadap indikator kinerja tidak difokuskan pada sektor-sektor yang vital dalam arti sektorsektor yang berkaitan langsung dengan peningkatan kesejahteraan seperti bidang pendidikan, kesehatan, dan kesempatan kerja. Seyogyanya indikator kinerja pemerintah dari sisi outcome atau hasil akhir dari pelbagai kegiatan yang berhubungan langsung dengan kesejahteraan masyarakat yaitu Human Development Index (HDI). Indikator ini layak digunakan untuk menggambarkan keberhasilan pemerintah dalam memperbaiki tingkat kesejahteraan dalam bidang kesehatan, pendidikan dan perekonomian masyarakat. Indikator keberhasilan kegiatan pinjaman dana perkuatan modal usaha KUMKMmenurut mekanisme penyaluran dana perkuatan modal usaha KUMKM sejak tahuntahun 2003 adalah :

1. Penyaluran pinjaman dana bergulir

2. Pengembalianpinjaman danabergulir

3. Penagihan pinjaman dana bergulir

4. Peningkatan sumber daya manusia KUMKM

5. Layanan lainnya seperti pemberian informasi yang terkait dengan pembiayaanpembangunan usaha.

Apabila pelaksanaan pekerjaan telah sesuai sebagaimana mekanisme penyaluran dana yang ditetapkan, maka kegiatankegiatan di atas baru memenuhi siklus manajemen input, proses dan output. Hasil akhir, benefit dan impak terhadap peningkatan kesejahteraan penerima belum terpenuhi. Kinerja pemerintah Provinsi 
Lampung dapat dinilai dari sampai seberapa jauh masalah sosial ekonomi masyarakat telah teratasi oleh penyaluran dana perkuatan modal usaha KUMKM tersebut. Secara umum, indikator keberhasilan pemerintah daerah antara lain : Indikator pertama adalah efektivitas yaitu tingkat ketercapaian tujuan,atau memenuhi kebutuhan atau masalah Sosial ekonomi yang dihadapi, baik dalamarti ketepatan pencapaian output, maupun pencapaian outcome. Indikator kedua adalah efisiensi yaitu apakah rasio antara outputatau outcome dengan biaya yang dikeluarkan. Indikator ketiga adalah relevansi, yaitu apakah program yang diusulkan untuk diimplementasikan benar-benar sesuai dengantujuan, kebutuhan, atau masalah sosial ekonomi yang dihadapi. Indikator keempat adalah keekonomian (economy) yaitu apakah pelbagai input yang dibutuhkan dalam program atau organisasi diperoleh dengan harga yang wajar dan dengan kualitas yang memadai. Indikator kelima adalah keberlanjutan dari hasil yang dicapai yaitu apakah kebutuhan masyarakat (sosial ekonomi) dicapai secara berkelanjutan.

\section{Penyaluran Dana Perkuatan Modal Usaha KUMKM}

\section{a. Penyaluran Dana Oleh Tim Perkuatan Permodalan KUMKM}

\footnotetext{
Kepedulian Pemerintah Provinsi Lampung untuk memberi perkuatan permodalan bagi KUMKM sudah digagas sejak tahun 2003 melalui surat Keputusan Gubernur Lampung Nomor 30 Tahun 2003 tentang Mekanisme Penyaluran Dana Bergilir UKM yang bersifat revolving atau bergulir di Provinsi Lampung. Gagasan tersebut akhirnya diwujudkan ke dalam Kegiatan Pinjaman Dana Perkuatan Modal Usaha KUMKM dengan sumber dana dari APBD Provinsi Lampung dilaksanakan pada tahun anggaran 2003. Selanjutnya kegiatan
}

serupa dilakukan pada tahun 2004 dan 2006. Kegiatan Pinjaman Dana Bergulir bertujuan mengembangkan dukungan permodalan usaha Koperasi dan UMKM yang potensial untuk mengembangkan usahanya namun belum tersedia pembiayaan secara memadai dari lembaga keuangan yang ada.

Berdasarkan data dan informasi yang telah diterima dari UPTD Perkuatan Permodalan KUMKM bahwa volume penyaluran dana perkuatan modal usaha KUMKM dari tahun 2003 s/d 2012 sampai dengan 31 Desember 2012 mencapaiRp. 27,500 miliar dengan jumlah KUMKM penerima dana nerjumlah 1.750 unit.Setelah dilakukan monitoring dan evaluasi oleh UPTD Perkuatan PermodalanKUMKM, diketahui bahwa terjadi perbedaan data pelaku usaha yang mendapat pinjaman dana perkuatan modal usaha KUMKM. Perbedaan data setelah dicocokkan dilapangan ternyata tidak sama sebagaimana data yang diperoleh dari Tim Penyalur Dana Perkuatan Modal Usaha KUMKM sejak tahun 2003 s/d 2007. Perbedaan data itu antara lain sebagian kecil dari penerima dana perkuatan modal usaha KUMKM menyatakan mereka tidak pernah menerima dana sama sekali. Nama mereka hanya digunakan untuk menutupi orang yang sebenarnya menerima dana perkuatan modal usaha tersebut. Biasanya hal ini dilakukan oleh seseorang yang mempunyai usaha akan tetapi tidak mempunyai agunan sebagai salah satu syarat yang harus dipenuhi oleh setiap peminjam disamping syarat tertentu lainnya. Perbedaan data juga sudah banyak terjadi, sebagian penerima menyatakan usaha mereka sudah mengalami kebangkrutan dan sudah berubah jenis usahanya. 


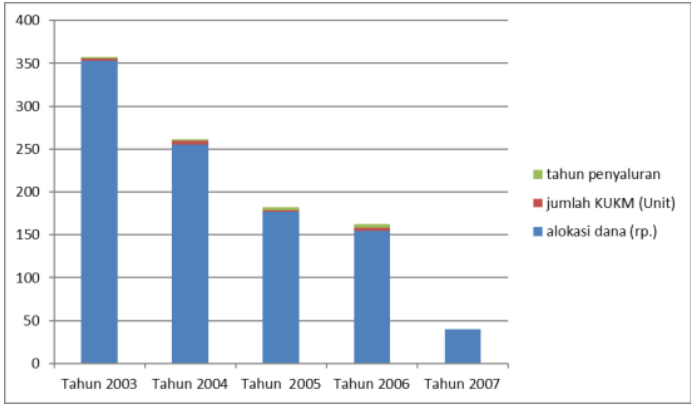

Sumber : UPTD PP-KUMKM tahun 2012

Tabel 1 menunjukkan jumlah KUMKM penerima alokasi dana APBD dalam program pinjaman dana perkuatan modal usaha KUMKM oleh Tim Pelaksana Program Perkuatan Modal Usaha KUMKM Dinas Koperasi UMKM Perindustrian dan Perdagangan Provinsi Lampung.

Tabel 1 : penerima pinjaman dana perkuatan modal usaha KUMKM di Provinsi Lampung tahun 2003-2007

\begin{tabular}{|c|l|l|l|}
\hline $\begin{array}{c}\text { No } \\
\cdot\end{array}$ & \multicolumn{1}{|c|}{$\begin{array}{c}\text { Tahun } \\
\text { penyaluran }\end{array}$} & $\begin{array}{c}\text { Jumlah } \\
\text { KUMKM } \\
\text { (Unit) }\end{array}$ & Alokasi Dana \\
\hline 1 & Tahun 2003 & 360 & 4.550 .000 .000 \\
\hline 2 & Tahun 2004 & 275 & 4.000 .000 .000 \\
\hline 3 & Tahun 2005 & 130 & 1.450 .000 .000 \\
\hline 4 & Tahun 2006 & 120 & 1.500 .000 .000 \\
\hline 5 & Tahun 2007 & 40 & 500.000 .000 \\
\hline & JUMLAH & 925 & 12.000 .000 .000 \\
\hline
\end{tabular}

Sumber : UPTD PP-KUMKIM Tahun 2012

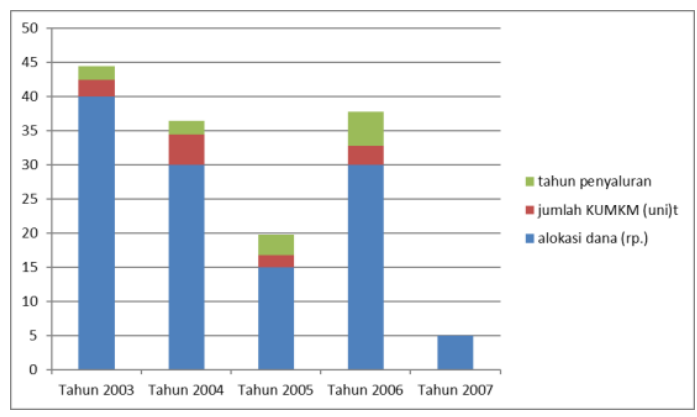

Sumber: UPTD PP-KUMKM Tahun 2012

Tabel 2 : Penerima pinjaman dana perkuatan modal usaha KUMKM di Kota Lampung Tahun 2003-2007

\begin{tabular}{|c|l|l|l|}
\hline $\begin{array}{c}\text { No } \\
\cdot\end{array}$ & $\begin{array}{c}\text { Tahun } \\
\text { penyaluran }\end{array}$ & $\begin{array}{c}\text { Jumlah } \\
\text { KUMKM } \\
\text { (Unit) }\end{array}$ & Alokasi Dana \\
\hline 1 & Tahun 2003 & 40 & 550.000 .000 \\
\hline 2 & Tahun 2004 & 30 & 375.000 .000 \\
\hline 3 & Tahun 2005 & 15 & 240.000 .000 \\
\hline 4 & Tahun 2006 & 30 & 380.000 .000 \\
\hline 5 & Tahun 2007 & 5 & 75.000 .000 \\
\hline & JUMLAH & 120 & 1.620 .000 .000 \\
\hline
\end{tabular}

Sumber : UPTD PP-KUMKIM Tahun 2012

Penyaluran dana perkuatan modal usaha KUMKM yang telah diberikan kepada KUMKM juga telah diberikan kepada KUMKM yang berada di Kota Bandar Lampung sejak tahun 2003. Penyaluran dana perkuatan modal usaha KUMKM dilakukan oleh Tim Pelaksana Program Perkuatan Modal Usaha KUMKM dari tahun2003 s/d 2007 dapat digambarkan pada tabel 2 sebagai berikut.

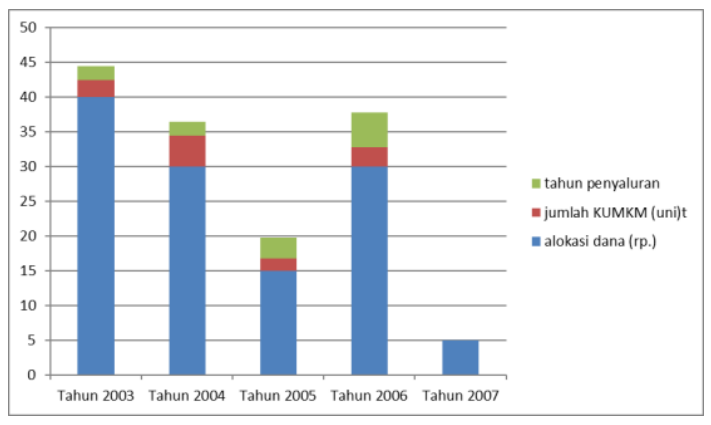

Sumber: UPTD PP-KUMKM Tahun 2012

Tabel 2 : Penerima pinjaman dana perkuatan modal usaha KUMKM di Kota Lampung Tahun 2003-2007

\begin{tabular}{|c|l|l|l|}
\hline $\begin{array}{c}\text { No } \\
\cdot\end{array}$ & \multicolumn{1}{|c|}{$\begin{array}{c}\text { Tahun } \\
\text { penyaluran }\end{array}$} & $\begin{array}{c}\text { Jumlah } \\
\text { KUMK } \\
\text { M (Unit) }\end{array}$ & Alokasi Dana \\
\hline 1 & Tahun 2003 & 40 & 550.000 .000 \\
\hline 2 & Tahun 2004 & 30 & 375.000 .000 \\
\hline 3 & Tahun 2005 & 15 & 240.000 .000 \\
\hline 4 & Tahun 2006 & 30 & 380.000 .000 \\
\hline 5 & Tahun 2007 & 5 & 75.000 .000 \\
\hline & JUMLAH & 120 & 1.620 .000 .000 \\
\hline
\end{tabular}


Sumber : UPTD PP-KUMKIM Tahun 2012

Penyaluran pinjaman dana perkuatan modal usaha KUMKM oleh TimPelaksana Program Perkuatan Modal Usaha KUMKM Dinas Koperasi UMKM Perindustrian dan Perdagangan Provinsi Lampung, dari sejak penyaluran tahun 2003 s/d 2007 dana pokok perkuatan modal usaha KUMKM yang disalurkan pada KUMKMyang berada Kota Bandar Lampung sebesar Rp. 1.620.000.000,- yang diberikan kepada120 KUMKM. Perkuatan modal usaha KUMKM tersebut diberikan kepada KUMKMsecara perorangan maupun kepada kelompok yang berbentuk Koperasi maupunLembaga Keuangan Mikro (LKM), contohnya UKM pengrajin meubelair di KecamatanRajabasa, UKM perdagangan di Kecamatan Sukarame, UKM sulaman usus dan tapis diKecamatan Tanjung Karamg Pusat, adapun UKM penghasil produk makanan, baikmakanan kecil (kerupuk dan keripik), pengrajin kue, rata-rata bersifat perseorangan berada di Kecamatan Kedaton Selain itu, jenis usaha perseorangan adalah usaha warung makanan, bengkel las, percetakan dan lain-lain. Dan untuk penyaluran pinjaman kepada lembaga usaha diberikan kepada Koperasi Mitra Usaha Madani di Kecamatan Kemiling, KJKS Lampung Sai Madani di Kecamatan Tanjung KarangTimur.

Hasil identifikasi terhadap tunggakan berjalan penerima kredit dana perkuatan modal usaha, jenis usaha perdagangan paling tinggi apabila dibanding dengan jenis usaha lainnya. Sedangkan untuk UKM Industri dan untuk koperasi tidak mengalami tunggakan pinjaman. Terjadinya tunggakan pada usaha perdagangan ini sesuai dengan permasalahan yang dihadapi UKM pada umumnya menyatakan bahwa dana perkuatan modal usaha tersebut adalah merupakan dana permerintah yang tidak harus dikembalikan atau hibah, permasalahan ini salah satunya dikarenakan kurangnya pembinaan dan monitoring dan evaluasi yang di laksanakan oleh Dinas Koperasi UMKM dan Perindag Provinsi Lampung, dan disamping itu juga terjadinya pailit yang ditandai dengan tidak operasionalnya usaha KUMKM penerima pinjaman tersebut.

\section{b. Penyaluran Dana Perkuatan Permodalan KUMKM oleh UPTD PerkuatanPermodalan KUMKM}

UPTD Perkuatan Permodalan KUMKM dibentuk berdasarkan Peraturan Gubernur Lampung No. 30 tahun 2007 tentang Pembentukan Badan Layanan Umum Daerah pada Dinas Koperasi Perindustrian dan Perdagangan Provinsi Lampung dan Peraturan Gubernur No. 14 Tahun 2008 tentang Pembentukan, Organisasi dan Tata Kerja Unit Pelaksana Teknis Dinas (UPTD) pada Dinas Daerah Provinsi Lampung. Berdasarkan Peraturan Gubernur tersebut UPTD Perkuatan Permodalan KUMKM mempunyai fungsi sebagai lembaga pengelola dana perkuatan modal usaha KUMKM di bawah Dinas Koperasi, UMKM Perindustrian dan Perdagangan Provinsi sejak tahun 2008. Perkembangaan pengelolaan dana perkuatan modal usaha sebagai hasil Revolving sejak tahun 2008 s/d 2012 untuk KUMKM dapat disajikan data sebagai berikut :

Tabel 3 : Penerima Pinjaman Dana Perkuatan Modal Usaha KUMKM di Provinsi Lampung Hasil Revolving Fund Tahun 2008-2012

\begin{tabular}{|c|l|l|l|}
\hline $\begin{array}{c}\text { No } \\
\cdot\end{array}$ & \multicolumn{1}{|c|}{$\begin{array}{c}\text { Tahun } \\
\text { penyaluran }\end{array}$} & $\begin{array}{c}\text { Jumlah } \\
\text { KUMK } \\
\text { M (Unit) }\end{array}$ & $\begin{array}{c}\text { Alokasi Dana } \\
(\text { Rp.000) }\end{array}$ \\
\hline 1 & Tahun 2003 & 130 & 2.500 .000 .000 \\
\hline 2 & Tahun 2004 & 135 & 2.750 .000 .000 \\
\hline 3 & Tahun 2005 & 185 & 3.500 .000 .000 \\
\hline
\end{tabular}




\begin{tabular}{|c|l|l|l|}
4 & Tahun 2006 & 210 & 3.750 .000 .000 \\
\hline 5 & Tahun 2007 & 165 & 3.000 .000 .000 \\
\hline & JUMLAH & 825 & 15.500 .000 .000 \\
\hline
\end{tabular}

Sumber : UPTD PP-KUMKIM Tahun 2012

Berdasarkan identifikasi data penyaluran dapat disimpulkan bahwa penyaluran dana perkuatan modal usaha KUMKM yang berada wilayah Kota Bandar Lampungadalah morupakan penyaluran dana yang paling tinggi apabila dibandingkan denganKUMKM yang berada di wilayah Kabupaten/Kota lainnya. Tingginya penyaluran dana di Kota Bandar Lampung disebabkan adanya beberapa hal seperti (1) Jarak tempuh KUMKM dengan UPTD Perkuatan Permodalan KUMKM yang lebih dekat, (2) Tingginya jumlah KUMKM (3) Informasi yang diterima KUMKM sehingga banyak KUMKM yang mengajukan permohonan pinjaman dan (4) Bayaknya KUMKM yang layak untuk menerima pinjaman. Sedangkan untuk penyaluran dana perkuatan modal usaha untuk KUMKM yang berada di wilayah Kota Bandar Lampung dapat disajikan sebagai berikut:

Tabel 3 : Penerima Pinjaman Dana Perkuatan Modal Usaha KUMKM di Kota Lampung Hasil Revolving Fund Tahun 2008-2012

\begin{tabular}{|c|l|l|l|}
\hline $\begin{array}{c}\text { No } \\
\cdot\end{array}$ & \multicolumn{1}{|c|}{$\begin{array}{c}\text { Tahun } \\
\text { penyaluran }\end{array}$} & $\begin{array}{c}\text { Jumlah } \\
\text { KUMKM } \\
(\text { Unit })\end{array}$ & $\begin{array}{c}\text { Alokasi Dana } \\
\text { (Rp.000) }\end{array}$ \\
\hline 1 & Tahun 2003 & 23 & 410.000 \\
\hline 2 & Tahun 2004 & 15 & 320.000 \\
\hline 3 & Tahun 2005 & 20 & 270.000 \\
\hline 4 & Tahun 2006 & 25 & 450.000 \\
\hline 5 & Tahun 2007 & 30 & 712.000 \\
\hline & JUMLAH & 113 & 2.162 .000 \\
\hline
\end{tabular}

Sumber : UPTD PP-KUMKIM Tahun 2012
Perkembangan penyaluran dana perkuatan modal usaha yang berupa Revolving Fund yang disalurkan oleh UPTD Perkuatan PermodalanKUMKM periode tahun 2008 s/d 2012 dana pokok perkuatan modal usaha KUMKM yang disalurkan pada KUMKM yang berada Kota Bandar Lampung pada posisi 31 Desember 2012 sebesar Rp 2.162.000.000,- yang diberikan kepada 113 KUMKM. Penyaluran dana perkuatan modal usaha KUMKM di Kota Bandar Lampung seperti pada penyaluran dana yang telah dilaksanakan oleh Tim Pelaksana Program Dana Perkuatan modal KUMKM padaperiode tahun 2003 s/d 2007. Penerima dana perkuatan ini diberikan kepada KUMKM secara perorangan maupun kepada kelompok yang berbentuk Koperasi atau Lembaga Keuangan Mikro (LKM) seperti pengrajin meubelair/kusen, di Kecamatan Tanjung Karang Timur, pengrajin kripik di Kecamatan Rajabasa, pengrajin sulam usus di Kecamatan Tanjung Karang Pusat, adapun UKM penghasil produk makanan, baik makanan kecil (kerupuk dan keripik), pengrajin kue, ratarata bersifat perseorangan berada di Kecamatan Kedaton, Kecamatan, Teluk Betung Selatan serta di berbagai kecamatan yang ada di Kota Bandar Lampung seperti pedagang sembako, usaha warung makanan, dan lain-lain. Dan untuk penyaluran pinjaman kepada lembaga usaha diberikan kepada 6 unit Koperasi yang berada di Kecamatan Tanjung Karang Pusat, Kecamatan Kemiling dan Kecamatan Sukarame.

Hasil identifikasi terhadap tunggakan berjalan penerima kredit dana perkuatan modal usaha, jenis usaha perdagangan tetap menempati urutan paling tinggi dibanding dengan usaha lainnya. Permsalahan ini salah satunya dikarenakan kurangnya pembinaan dan monitoring dan evaluasi yang di laksanakan oleh UPTD Perkuatan 
Permodalan KUMKM, dan disamping itu juga terjadinya pailit yang ditandai dengan tidak operasionalnya usaha KUMKM penerima pinjaman tersebut.

Karakteristik responden dari penelitian ini dapat digambarkan sebagai berikut :Jenis kelamin 102 responden terdiri dari $25 \%$ penerima kredit adalah perempuan, sedangkan $75 \%$ adalah laki-laki. Latar belakang pendidikan para penerima kredit adalah sebanyak $49 \%$ tidak pernah lulus pendidikan dasar, $30 \%$ menyelesaikan pendidikan dasar, selanjutnya $16 \%$ menyelesaikan pendidikan menengah di sekolah menengah pertama. Sebanyak $6 \%$ memiliki ijazah sekolah menengah atas dan hanya $1 \%$ atau 1 orang yang menyelesaikan pendidikan sarjana.

Gambar 1: Karakteristik Responden (dalam orang)
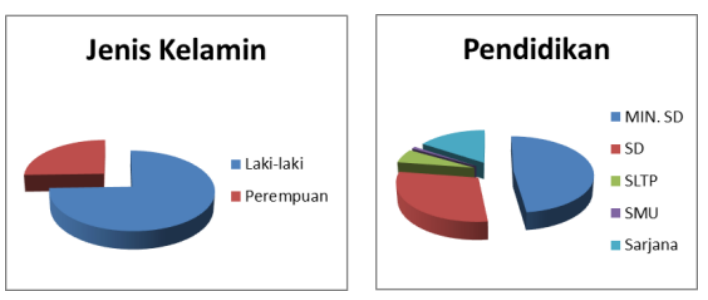

\section{Usaha yang Dibiayai}

Usaha yang dibiayai dalam kegiatan ini mencakup sektor perindustrian, perdagangan dan jasa baik yang tergabung dalam koperasi, LKM maupun perorangan (UMKM). Penentuan jenis usaha yang layak mendapat bantuan dana bergulir mengacu pada kriteria dan persyaratan yang telah ditetapkan oleh UPTD Perkuatan Permodalan Koperasi dan UMKM sebagaimana tercantum dalam Peraturan Gubenur LampungNomor 39 Tahun 2008 tentang Rencana Strategis Bisnis, Pola Tata Kelola, dan Standar Pelayanan Minimal Badan Layanan Umum Daerah (BLUD) UPTD Perkuatan Permodalan KUMKM. Mengingat sifat kegiatan ini adalah mendukung permodalan usaha maka syaratsyarat yang harus dipenuhi penerima dana antara lain: (1) Memiliki usaha produktif (2) Mengelola usaha minimal 1 tahun (3) Memiliki tempat usaha tetap yang dijelaskan dg surat izin usaha (4) Tidak sedang memperoleh pinjaman dana lembaga lain untuk usaha yang sama (5) Memiliki jaminan berupa sertifikat tanah.

Besar kecilnya alokasi anggaran untuk Kegiatan Pinjaman Dana Perkuatan modal Usaha KUMKM tidak sama setiap tahunnya, tergantung dari ketersediaan dana hasil revolving atau angsuran pokok yang telah dibayarkan oleh KUMKM penerima dana kepada UPTD Perkuatan Permodalan KUMKM melalui Bank Lampung. Besarnya jumlah yang disalurkan pada masing-masing UKM juga dipengaruhi oleh hasil seleksi kelayakan usaha yang telah dilakukan oleh tim survey dari UPTD PerkuatanPermodalan KUMKM. Besarnya pinjaman dana bergulir yang diberikan kepada masing-masing unit usaha UKM pada tahun $2003 \mathrm{~s} / \mathrm{d}$ 2012, ratarata sebesar Rp.15.000.000,-. Dana tersebut, mereka terima secara langsung dari Bank Lampung. Lama pembayaran melalui angsuran atau cicilan selama 2 (dua) tahun dengan tingkat jasa/bunga sebesar $6 \%$ per tahun secara flat dari pokok pinjaman dan tenggang waktu 3 bulan setelah diterimanya kredit bagi KUMKM peminjam baru sedangkan untuk KUMKM peminjan lanjutan tidak dikenakan tenggang waktu 3 bulan atau langsung membayar angsuran pinjaman pada bulan berikutnya setelah dana diterima.

\section{Evaluasi Pelaksanaan Pinjaman Dana Perkuatan Permodalan KUMKM Tahun 2008 s/d 2012}

Untuk mengetahui sejauh mana keberhasilan pelaksanaan pinjaman dana perkuatan modal usaha, maka digunakan indikator kinerja organisasi pemerintah 
berdasarkan pada siklus manajemen terhadap input, proses dan output dari kegiatan (Muhammad, 2008). Hasil yang diharapkan dari penelitian ini adalah dapat menggambarkan keberhasilan dan faktorfaktor yang mempengaruhi, termasuk kendala dan hambatan selama pelaksanaan kegiatan dimaksud. Dari hasil jawaban para responden penelitian,diperolehsecararinci, informasi dan data pada setiap tahapan pelaksanaan kegiatan.

\section{a. Evaluasi Input}

Evaluasi terhadap input dari kegiatan pinjaman dana perkuatan modal usaha adalah nilai pinjaman yang diterima UKM dan lembaga pendamping dan Pembina bagiKUMKM

\section{1) Nilai Pinjaman}

Tabel 4 : Persentasi Pengembalian pinjaman dana perkuatan modal usaha KUMKM di Kota Bandar Lampung 2008 s/d 2012

\begin{tabular}{|c|c|c|c|c|c|c|c|c|c|}
\hline \multirow{2}{*}{ No } & \multirow{2}{*}{ Kecamatan } & \multirow{2}{*}{$\begin{array}{c}\mathrm{Jml} \\
\mathrm{UKM}\end{array}$} & \multirow{2}{*}{ Realisasi } & \multicolumn{2}{|c|}{$\begin{array}{c}\text { Jumlah angsuran } \\
\text { seharusnya }\end{array}$} & \multicolumn{2}{|c|}{$\begin{array}{c}\text { Jumlah } \\
\text { tunggakan }\end{array}$} & \multirow{2}{*}{$\begin{array}{c}\text { Tunggakan } \\
\text { pokok } \%\end{array}$} & \multirow{2}{*}{$\begin{array}{c}\text { Angsuran } \\
\text { pokok \% }\end{array}$} \\
\hline & & & & Pokok & Jasa & Pokok & Jasa & & \\
\hline I & Tahun 2008 & & & & & & & & \\
\hline 1 & Sukarame & 8 & 150,000 & $\begin{array}{c}150,00 \\
0\end{array}$ & 18,000 & 52,560 & 6,300 & 35 & 65 \\
\hline 2 & Tanjung senang & 5 & 85,000 & 85,000 & 10,200 & 24,340 & 3,680 & 29 & 71 \\
\hline 3 & Kedaton & 7 & 120,000 & $\begin{array}{c}120,00 \\
0\end{array}$ & 14,400 & 33,520 & 5,201 & 28 & 72 \\
\hline \multirow[t]{2}{*}{4} & Rajabasa & 3 & 55,000 & 55,000 & 6,000 & 22,250 & 2,301 & 40 & 60 \\
\hline & Jumlah & 23 & 140,000 & $\begin{array}{c}140,00 \\
0\end{array}$ & 49,200 & $\begin{array}{c}132,67 \\
0\end{array}$ & 17,482 & 32 & 68 \\
\hline II & Tahun 2009 & & & & & & & & \\
\hline 1 & Tj. Karang timur & 6 & 130,000 & $\begin{array}{c}130,00 \\
0\end{array}$ & 15,600 & 47,500 & 7,660 & 37 & 63 \\
\hline 2 & Tj. Karang Pusat & 3 & 105,000 & $\begin{array}{c}105,00 \\
0\end{array}$ & 12,600 & 34,720 & 4,950 & 33 & 67 \\
\hline 3 & Rajabasa & 4 & 85,000 & 85,000 & 10,200 & 29,800 & 6,630 & 35 & 65 \\
\hline
\end{tabular}

Hasil rekap pengembalian pinjaman
dana perkuatan modal usaha KUMKM diKota Bandar Lampung seperti pada tabel 4 di bawah ini menunjukkan setiap unit usaharata-rata menerima kredit dana bergulir untuk perorangan memperoleh dana dibawahrata-rata antara Rp.5.000.000 s/d 15.000.000 Hanya 30 unit usaha yang menerima dana rata-rata yaitu antara Rp.15.000.000,- $\quad$ s/d Rp.20.000.000,sebanyak 60 unitusaha dan yang menerima dana di atas rata-rata mencapai 23 unit usaha. Berdasarkan informasi yang telah disampaikan oleh UPTD Perkuatan Permodalan KUMKM, bahwaKUMKM yang menerima dana pinjaman lebih besar adalah merupakan pinjaman lanjutan dan menunjukan perkembangan usahanya yang lebih meningkat. Kinerja pengembalian pinjaman dana perkuatan madal usaha yang ada diwilayah Kota Bandar Lampung dapat disajikan sebagai berikut:

\section{Bandar Lampung 2008 s/d 2012}




\begin{tabular}{|c|c|c|c|c|c|c|c|c|c|}
\hline & Jumlah & 15 & 320,000 & $\begin{array}{c}320,00 \\
0\end{array}$ & 38,400 & $\begin{array}{c}112,02 \\
0\end{array}$ & 19,240 & 35 & 65 \\
\hline III & Tahun 2010 & & & & & & & & \\
\hline 1 & Kemiling & 6 & 87,000 & 87,000 & 10,440 & 24,580 & 4,786 & 28 & 72 \\
\hline 2 & Sukarame & 4 & 43,000 & 43,000 & 5,160 & 12,620 & 2,354 & 29 & 71 \\
\hline 3 & Panjang & 7 & 105,000 & $\begin{array}{c}105,00 \\
0\end{array}$ & 12,600 & 31,700 & 7,190 & 30 & 70 \\
\hline 4 & Tb. Selatan & 3 & 35,000 & 35,000 & 4,200 & 8,900 & 2,730 & 25 & 75 \\
\hline & Jumlah & 20 & 270,000 & $\begin{array}{c}270,00 \\
0\end{array}$ & 32,400 & 77,800 & 17,060 & 29 & 71 \\
\hline IV & Tahun 2011 & & & & & & & & \\
\hline 1 & Tb. Utara & 4 & 55,000 & 35,000 & 4,600 & 11,500 & 4,786 & 21 & 79 \\
\hline 2 & Kedaton & 7 & 150,000 & 85,000 & 12,400 & 26,500 & 3,750 & 24 & 76 \\
\hline 3 & Panjang & 5 & 75,000 & 45,000 & 7,600 & 13,750 & 2,350 & 18 & 82 \\
\hline 4 & Way Halim & 8 & 115,000 & 95,000 & 10,400 & 27,800 & 3,250 & 24 & 76 \\
\hline 5 & Kemiling & 6 & 95,000 & 50,000 & 7,600 & 17,500 & 2,280 & 18 & 82 \\
\hline & Jumlah & 30 & 450,000 & $\begin{array}{c}310,00 \\
0\end{array}$ & 42,600 & 97,050 & 12,980 & 22 & 78 \\
\hline $\mathrm{V}$ & Tahun 2012 & & & & & & & & \\
\hline 1 & Sukarame & 3 & 45,000 & 11,250 & 1,500 & 3,700 & 300 & 33 & 67 \\
\hline 2 & Kemiling & 7 & 155,000 & 25,833 & 2,8000 & 6,166 & 570 & 24 & 76 \\
\hline 3 & $\mathrm{Tj}$. Karang timur & 4 & 90,000 & 15,000 & 2,325 & 3,500 & 465 & 23 & 77 \\
\hline 4 & Tj. Karang Pusat & 3 & 87,000 & 10,875 & 2,700 & 2,175 & 540 & 20 & 80 \\
\hline 5 & Way Halim & 3 & 130,000 & 16,250 & 2,610 & 3,245 & 342 & 20 & 80 \\
\hline 6 & Panjang & 2 & 35,000 & 8,750 & 3,900 & 1,750 & 780 & 20 & 80 \\
\hline 7 & Langkapura & 1 & 30,000 & 6,000 & 1,400 & 5,000 & 450 & 83 & 17 \\
\hline 8 & Kedaton & 3 & 65,000 & 16,250 & 900 & 3,250 & 180 & 20 & 80 \\
\hline 9 & Tb. Selatan & 1 & 15,000 & 1,875 & 1,950 & 2,450 & 225 & 114 & (14) \\
\hline 10 & Tb. Utara & 1 & 20,000 & 5,000 & 450 & 1,250 & 90 & 25 & 75 \\
\hline 11 & Tanjung senang & 1 & 15,000 & 3,750 & 800 & 2,450 & 225 & 57 & 43 \\
\hline 12 & Rajabasa & 1 & 25,000 & 6,252 & 600 & 3,102 & 375 & 50 & 50 \\
\hline
\end{tabular}




\begin{tabular}{|c|c|c|c|c|c|c|c|c|c|} 
& Jumlah & 30 & 712,000 & $\begin{array}{c}127,08 \\
5\end{array}$ & 21,935 & 37,428 & 4,542 & 29 & 71 \\
\hline & Total & 113 & $\begin{array}{c}2.162 .00 \\
0\end{array}$ & $\begin{array}{c}1.437 . \\
085\end{array}$ & $\begin{array}{c}184.53 \\
5\end{array}$ & $\begin{array}{c}456.96 \\
8\end{array}$ & 71.304 & 29,4 & 70,6 \\
\hline
\end{tabular}

Sumber : UPTD Perkuatan Permodalan KUMKM Tahun 2012

Berdasarkan perhitungan hasil penilitian sebagaimana tabel 4, bahwa pengembalian pinjaman dana perkuatan modal usahaKUMK di wilayah Kota Bandar Lampung dari tahun 2006 s/d 2012, dengan beban bunga sebesar 6 persen pertahun (24bulan) ternyata secara rata-rata pada setiap tahun penyaluran terdapat tunggakan sebesar 29,4\%. Dari total pokok pinjaman yang harus dibayarkan oleh peminjam sebesar Rp 1.437. 085.000,- yang diterima oleh 113 KUMKM masih terjadi penunggakan pokok sebesar Rp. 456.968.000.-. Hal ini berarti bahwa pelaksanaan program penyaluaran dana perkuatan modal usaha KUMKM yang diselenggarakan olehUPTD Perkaatan Permodalan KUMKM masih terdapat beberapa kelemahan yang perkuatan modal usaha tidak dipengaruhi oleh besar kecilnya jumlah dana yang diberikan kepada KUMKM, namun sangat dipengaruhi oleh penyalur (UPTD Perkuatan Permodalan KUMKM) dan KUMKM penerima kredit. Peran dan tugas para Pihak tersebut sangat menentukan keberhasilan program. Tersalurkannya dana kegiatan seluruhnya bukanlah indikasi keberhasilan suatu kegiatan pembangunan, tapi juga harus memperhatikan keberhasilan tingkat pengembalian.

Berdasarkan data yang diperoleh dari kuesioner, walaupun memakan waktu paling lama 6 (enam) bulan dari pengajuan proposal hingga danakreditcair, proses pengajuan dan pencairan dana kredit adalah mudah. Namuntingginya kemacetan angsuran pinjaman pada tahun $2008 \mathrm{~s} / \mathrm{d}$ 2012, berdasarkan hasil wawancara, disebabkan adanya salah anggapan mengenai dana tersebut. Sebagian besar responden beranggapan pinjaman dana bergulir tersebut tidak dikenakan bunga (70\%), bahkan tidak perlu dikembalikan apabila usahanya bangkrut atau tidak berkembang.

\section{2) Lembaga Pendamping dan Pembina}

Sebagaimana model penyaluran dana bergulir yang dilakukan Grameen Bank,maka peran pendamping dan pembina memegang posisi penting untuk mendukungkeberhasilan program. Lembaga pendamping dan pembina dapat melakukan kunjunganrutin dan berkomunikasi, membahas berbagai kendala dan hambatan usaha yangdihadapi KUMKM. Lembaga pendamping dan pembina juga harus mengetahui aspekteknis produksi, pemasaran, pembukuan, keuangan yang dihadapi KUMKM tersebut.Lembaga pendamping dan pembina membantu para wirausaha dalam mengembangkanunit usahanya sehingga dana yang diterima tersebut tidak disalahgunakan.

Mekanisme penyaluran pinjaman dana perkuatan modal usaha KUMKM yang diselenggarakan Pemerintah Provinsi Lampung melalui UPTD Perkuatan Permodalan KUMKM, tidak memiliki struktur organisasi lembaga pendamping dan lembaga Pembina bagi para penerima dana perkuatan modal usaha. Merujuk Petunjuk Teknis (Juknis) Perkuatan Modal Usaha KUMKM sejak Tahun 2003 s/d 2012, tidak tercantum lembaga pendamping dan pembina yang bertugas mendampingi KUMKM penerima pinjaman. Juknis tersebut menyatakan bahwa UPTD PerkuatanPermodalanKUMKMselakuorgan 
isasi dan pelaksanakegiatanmelakukan koordinasi denganDinas/Instansi terkait, dan Bank Lampung untuk mempersiapkan program, melakukan monitoring dan evaluasi pelaksanaan program. Namun tidak ada Dinas/Instansi lain yang terlibat dalangprogram pendampingan.

Kegiatan monitoring dan evaluasi dilakukan oleh UPTD Perkuatan Permodalan KUMKM itu sendiri. Selama masa pengembalian angsuran pinjaman, memiliki tugas untuk memberikan pembinaan, konsultasi teknis mengenai pengelolaan administrasi pada KUMKM. Selain itu juga UPTD Perkuatan Permodalan KUMKM memiliki tugas melakukan pemantauan dan pengawasan atas pemanfaatan modal secara berkala, sekurang-kurangnya 3 (tiga) kali dalam 1 (satu) tahun. Artinya, UPTD Perkuatan Permodalan KUMKM seharusnya melakukan peran pendampingan dan pembinaan bagi KUMKM dalam mengelola administrasi sehingga penggunaan dana efektif dan optimal untuk meningkatkan usahanya.

Berdasarkan informasi yang diperoleh di lapangan, untuk penyaluran tahun2003 s/d 2007 oleh Tim Pelaksana Program Penyaluran Dana Perkuatan Modal KUMKM dan penyaluran dana tahun 2008 s/d 2012 oleh UPTD Perkuatan Permodalan KUMKM, setelah kredit dicairkan, tidak ada tenaga pendamping atau konsultan teknis bagi KUMKM dalam memanfaatkan dana pinjaman untuk mengembangkan usahanya, Pada saat mereka menghadapi masalah, mereka tidak tahu harus berkonsultasi dengan siapa. Ada sebagian penerima dana bersikap pasrah saat menghadapi masalah atau mengalami kebangkrutan. Akibat tidak adanya tenaga pendamping, maka banyak pelaku yang menunggak angsuran pinjaman, tidak menerima teguran atau sanksi. Pihak Bank Lampung juga tidak melakukan tugas konsultasi teknis sebagaimana yang diharapkan dalam Juknis kegiatan dana bergulir. Setelah terbentuknya UPTD Perkuatan permodalan KUMKM pemberian pendampingan dan pembinaan dapat dilakukan oleh tim yang berasal dari staf pada UPTD Perkuatan Permodalan KUMKM untuk memberikan pembinaan, pendampingan serta sekaligus mengadakan monitoring dari evaluasi pemanfaatan dan pengembalian pinjaman oleh KUMKM penerima dana Frekuensi pelaksanaan kegiatan pendampingan dan pembinaan yang dilaksanakan olehUPTD Perkuatan Permodalan KUMKM belum menunjukan kinerja yang optimal hal ini dikarenakan adanya berbagai keterbatasan yang dihadapi oleh UPTD Perkuatan permodalan KUMKM seperti kurangnya sarana mobilisasi, pendanaan dan staf yangada di UPTD padahal disisi lain tugas pokok dan fungsi UPTD Perkuatan Permodalan KUMKM sebagai lembaga pengelola dana perkuatan modal usaha mencakup wilayah kerja pada 14 Kabupaten/Kota dengan jumlah KUMKM pernerima dana mencapai1.750 KUMKM.

Hasil survey di lapangan yang menunjukkan tidak adanya tenaga pendamping dan pembina (dalam hal frekuensi dan kualitas) merupakan salah satu kelemahan dari mekanisme penyaluran pinjaman dana perkuatan modal usaha KUMKM. UPTDPerkuatan Permodalan KUMKM maupun Bank Lampung tidak mengadopsi model perkuatan permodalan seperti yang dilakukan Grameen Bank, dimana setiap minggu pihak Bank bertemu dengan sentra atau kelompok peminjam. Pertemuan rutin tersebut sangat membantu peminjam apabila menghadapi masalah. Berbagai permasalahan dibidang manajemen pemasaran maupun teknis produksi dapat langsung disampaikan dalam pertemuan rutin tersebut dan dicarikan 
alternatif penyelesaian masalah dan jalan keluarnya. Adanya bantuan pendamping dapat mengatasi kendala peminjam dalam mengembangkan usaha dan untuk membayar angsuran pinjaman.

\section{b. Evaluasi Proses}

Evaluasi terhadap proses pelaksanaan kegiatan pinjaman dana perkuatan modal usaha KUMKM dilakukan pada tahap-tahap sosialisasi, penyusunan proposal, seleksi, perjanjian, pelayanan dan pencairan kredit serta tanggung jawab dan pengawasan pemanfaatan dana kredit.

\section{1) Sosialisasi}

Kegiatan sosialisasi pada awal pelaksanaan program merupakan langkah penting untuk dilakukan sebaik mungkin kepada seluruh calon penerima program, agar terbentuk pemahaman masyarakat yang baik dan benar mengenai tujuan dan manfaat program. Berdasarkan Tabel 5 disajikan informasi bahwa sosialisasi dalam penyelenggaraan program dana bergulir yang dilakukan Pelaksana Teknis Kegiatanpada tahun 2003 s/d 2012 pada Dinas Koperasi, UMKM Perindustrian dan Perdagangan Provinsi Lampung maupun oleh UPTD Perkuatan Permodal KUMKM kurang baik. Kegiatan sosialisasi yang seharusnya dilaksanakan sebelum program penyaluran, untuk memberikan pemahaman kepada pihak-pihak terkait dan KUMKMcalon penerima pinjaman agar dapat sama-sama dan atau setiap unsur yang terlibat dalam pelaksanaan program dapat menjalankan hak dan kewajibannya masingmasing Sehingga tujuan pelaksanaan program dapat tercapai secara optimal.

Tabel 5 : Sosialisasi Dalam Penyelenggaraan Pinjaman Dana Modal Usaha di Kota Bandar Lampung Tahun 2003 s/d 2012

\begin{tabular}{|c|l|l|l|l|l|l|}
\hline No & \multicolumn{1}{|c|}{ Aspek } & $\begin{array}{c}\text { Sangat } \\
\text { baik }\end{array}$ & \multicolumn{1}{|c|}{ Baik } & \multicolumn{1}{c|}{ Cukup } & Kurang & $\begin{array}{l}\text { Sangat } \\
\text { kurang }\end{array}$ \\
\hline 1 & Pelaksanaan Sosialisai & 23,5 & 67,6 & 2,9 & 2,9 & 2,9 \\
\hline 2 & Petugas Yang Ditunjuk & 2,9 & 81,4 & 4,9 & 7,8 & 2,9 \\
\hline 3 & Kondisi Tempat Sosialisasi & 2,9 & 65,7 & 18,6 & 9,8 & 2,9 \\
\hline 4 & Pemahaman Sosialisasi & 15,7 & 67,6 & 13,7 & 0 & 2,9 \\
\hline 5 & Keikutsertaan Aparat Lain & 0 & 26,5 & 7,8 & 12,7 & 52,9 \\
\hline & Jumlah & 45,1 & 308,8 & 48 & 33,3 & 64,7 \\
\hline & Rata-rata & 9 & 61,8 & 9,6 & 6,7 & 12,9 \\
\hline
\end{tabular}

Sumber : Dana Primer

Hasil penelitian menunjukkan bahwa kegiatan sosialisasi hanya diberikan kepada dinas yang membidangi koperasi dan UKM pada 14 Kabupaten/Kota termasuk dinas yang membidangi koperasi dan UKM Kota Bandar Lampungdengan harapan petugas atau dinas yang membidangi koperasi dan UKM kabupaten/kota dapat melanjutkan memberikan sosialisasi di tingkat kabupaten/kota oleh petugas yang telah mengikuti kegiatan sosialisasi ditingkat provinsi. Data ini mendukung informasi mengenai tidakadanya lembaga instansi lain yang berfungsi sebagai tenaga pendamping dan pembina dalam program ini. Sebagian besar responden menyatakan pelaksanaan kegiatansosialisasi belum dapat di pahami dengan baik karena pemberian sosialisasi disampaikan oleh dinas yang membidangi koperasi dan UKM Kota Bandar Lampung tidak dapat dilaksanakan secara rutin atau berkala. Hanya sebagian kecil saja yang 
menyatakan mereka tidak pernah mengikuti sosialisasi sebelum menerima dana bergulir tersebut.

\section{2) Penyusunan Proposal}

Setelah kegiatan sosialisasi mengenai program pinjaman dana perkuatan modal usaha KUMKM dilakukan, maka bagi warga yang berminat diminta mengajukan permohonan pinjaman dengan melampirkan proposal kelayakan usaha. Untuk pemberian pemahaman dan keterampilan kepada KUMKM yang akan mengajukan proposal ternyata tidak dilakukan kegiatan pelatihan penyusunan proposalyang diikutioleh KUMKM . Tata cara penyusunan proposal diberikan secara sepintas pada waktu kegiatan sosialisasi sehingga KUMKM kurang memahami tata cara penyusunan proposal. Pemberian materi penyusunan proposal banyakdiberikanoleh petugas pada dinas yang membidangi Koperasi dan UKM kabupaten/kotakepada KUMKM yang datang untuk konsultasi penyusunan proposal dan bagi KUMKM yang tidak mempunyai kesempatan untuk datang ke dinas maka mereka akan meminta penjelasan kepada sesama KUMKM yang akan mengusulkan pinjaman. Hal ini menunjukan bahwa pemberian pembinaan penyusunan proposal belum dapat dilakukan secaraOptimal oleh UPTD Perkuatan Permodalan KUMKM, Tabel 6 menunjukkan sikap peserta yang menilai kurang atau lebihnya pendampingan penyusunan proposal oleh petugas.

Tabel 6 : Penyusunan Proposal Dalam Penyelenggaraan Pinjaman Dana Perkuatan Modal Usaha KUMKM di Kota Lampung Tahun 2003 s/d 2012

\begin{tabular}{|c|l|l|l|l|l|l|}
\hline No & \multicolumn{1}{|c|}{ Aspek } & $\begin{array}{c}\text { Sangat } \\
\text { baik }\end{array}$ & \multicolumn{1}{|c|}{ Baik } & \multicolumn{1}{c|}{ Cukup } & Kurang & $\begin{array}{l}\text { Sangat } \\
\text { kurang }\end{array}$ \\
\hline 1 & Ptugas terampil & 2,9 & 39,9 & 7,8 & 26,5 & 23,5 \\
\hline 2 & Petugas melayani dengan sabar & 2,9 & 39,2 & 15,7 & 18,6 & 23,5 \\
\hline 3 & Petugas melayani dengan baik & 2,9 & 28,4 & 18,5 & 23,8 & 26,5 \\
\hline 4 & Peserta menjadi terampil & 2,9 & 54,9 & 4,9 & 10,8 & 26,5 \\
\hline 5 & Peserta mampu menyusun proposal & 0 & 7,8 & 7,8 & 36,3 & 48 \\
\hline & Jumlah & 11,8 & 169,6 & 54,9 & 115,7 & 148 \\
\hline & Rata-rata & 2,4 & 33,9 & 11 & 23,1 & 29,6 \\
\hline
\end{tabular}

Sumber : Data Primer

Pelatihan penyusunan proposal merupakan salah satu cars agar KUMKM memiliki kemampuan menyiapkan dokumen-dokumen spebila Ingin mengajukan permohonan kredit ke lembaga perbankan atau bank-able, Salah satu kelemahan dari KUMKM di Indonesia adalah tidak memiliki posisi tawar yang baik terhadap lembaga perbankan untuk mengajukan bantuan permodalan. Pelatihan penyusunan proposaladalah pelatihan peningkatan kapasitas kelembagaan KUMKM.

Separuh responden menyatakan mereka menjadi terampil setelah mengikuti pelatihan penyusunan proposal kelayakan usaha. Namun jawaban tersebut tidakkonsisten dengan pertanyaan selanjutnya untuk memastikan jawaban mengenai tingkatkemampuan mereka dalam menyusun proposal-proposal usaha lain secara mandiri.Secara rata-rata, responden 
menyatakan kegiatan penyusunan proposal adalah baik namun tingkat kemampuan KUMKM dalam menyusun proposal usaha sebenarnya masih sangat kurang atau belum mampu menyusun proposal kelayakan usaha secaramandiri. Hal ini disebabkan oleh tidak adanya pelatihan penyusunan proposal yang dilakukan UPTD Perkuatan Permodalan KUMKM secara langsung diberikan kepada KUMKM dan disisi lain dinas yang membidangi koperasi dan UKM Kota Bandar Lampung yang diharapkan dapat memberikan pelatihan secara baik kepada KUMKMdi wilayah kerjanya akan tetapi dalam kenyataannya kegiatan pelatihan penyusunan proposal tersebut tidak dapat dilaksanakan secara baik.

\section{3) Seleksi Kelayakan Usaha}

Sesuai Petunjuk Teknis Perkuatan Modal Usaha KUMKM, Pelaksana kegiatan(Tim Survey) melakukan seleksi KUMKM yang mengajukan permohonan modal pinjaman untuk mengajukan permohonan pinjaman dana perkuatan modal usaha perludilengkapi rekomendasi dari dinas yang membidangi koperasi dan UKM kabupaten/kota setempat. Berdasarkan hasil analisis data terhadap seleksi kelayakan usaha yang dilaksanakan oleh Tim Pelaksana Program tahun 2003 s/d 2008 maupun UPTD Perkuatan Permodalan KUMKM tahun 2008 s/d 2012, dalam hal ini TimSurveydi KotaBandar Lampung. Maka hasilnya adalah separuh $(50 \%)$ dari responden menyatakan baik. Separuh responden menyatakan pelaksanaan seleksi kurang karena mereka menyatakan tidak pernah didatangi oleh aparat ke lokasi usaha dan dinilai kelayakan usaha yang bersangkutan. Namun sebagian lain menyatakan bahwa petugas yang datang dinilai menyampaikan dengan baik manfaat seleksi dan membahas hasil seleksi dengan calon penerima pinjaman.

Oleh karena itu, untuk selanjutnya, penyeleksian terhadap calon penerima kredit harus dilakukan lebih cermat. Pelaksanaan seleksiyang kurang baik membentuk persepsi calon penerima program yang tidak tepat tentang program yang akan digulirkan. Jika kegiatan pinjaman dana bergulir dipaksakan dapat menimbulkan banyaknya kredit macet dan menghambat perguliran dana tersebut bagi pelaku usahayang lebih bertanggung jawab. Pelaksanaan pinjaman dana bergulir pada tahun 2003s/d 2007 yang memegang prinsip pemerataan harus dihindari karena ternyata menghasilkan tunggakan berjalan yang sangat besar.

Temuan dari penelitian ini yang disampaikan dalam Tabel 7 menunjukkan bahwa sebanyak $63 \%$ responden menyatakan mereka tidak pernah diminta menyediakan agunan atau jaminan untuk disita apabila mereka menunggak atau tidakmelunasi pengembalian pinjaman modal tersebut. Merujuk Petunjuk Teknis kegiatan dana bergulir ini, memang penerima pinjaman tidak diminta menyediakan jaminan atau agunan apabila menunggak sebagaimana mekanisme penyaluran lembaga perbankan pada umumnya. Dalam hal ini, penerima akan mendapat sanksi berupa pengalihan hak pengelolaan dana apabila ada indikasi penyimpangan atau kelalaian.Tidak ada sanksi berupa penyitaan atas agunan biasanya disediakan peminjam apabila tidak mampu melunasi pinjaman.

Tabel 7 : Seleksi Kelayakan Usaha Dalam Penyelenggaraan Pinjaman Dana Perkuatan Modal Usaha KUMKM di Kota Bandar Lampung Tahun 2003 s/d 2012 (dalam \%)

\begin{tabular}{|l|l|c|c|c|c|c|}
\hline No & Aspek & $\begin{array}{c}\text { Sangat } \\
\text { baik }\end{array}$ & Baik & Cukup & Kurang & $\begin{array}{c}\text { Sangat } \\
\text { kurang }\end{array}$ \\
\hline
\end{tabular}




\begin{tabular}{|c|l|c|c|c|c|c|}
1 & Petugas menyeleksi tepat sasaran & 2,9 & 39,2 & 13,7 & 39,2 & 4,9 \\
\hline 2 & Petugas terampil menyeleksi & 2,9 & 57,8 & 15,7 & 18,6 & 4,9 \\
\hline 3 & $\begin{array}{l}\text { Petugas menjelaskan manfaat } \\
\text { seleksi }\end{array}$ & 0 & 47,1 & 9,8 & 40,2 & 2,9 \\
\hline 4 & $\begin{array}{l}\text { Bersama petugas membahas hasil } \\
\text { seleksi }\end{array}$ & 0 & 28,4 & 13,7 & 54,9 & 2,9 \\
\hline 5 & $\begin{array}{l}\text { Petugas mampu menilai kelayakan } \\
\text { usaha }\end{array}$ & 0 & 34,4 & 225 & 34,3 & 5,9 \\
\hline 6 & $\begin{array}{l}\text { Peserta mampu } \\
\text { menyediakanagunan }\end{array}$ & 0 & 0 & 5,9 & 31,4 & 62,7 \\
\hline & Jumlah & 5,9 & 206,9 & 84,3 & 218,6 & 84,3 \\
\hline & Rata-rata & 1 & 34,5 & 14,1 & 36,4 & 14,1 \\
\hline
\end{tabular}

\section{Sumber : Data Primer}

\section{4) Perjanjian}

Setelah melalui proses seleksi, UPTD Perkuatan Permodalan KUMKM melalui Tim Survey menetapkan nama-nama penerima pinjaman dana bergulir melalui surat Keputusan Kepala UPTD Perkuatan Permodalan KUMKM. Surat keputusan tersebut menyatakan KUMKM yang ditetapkan sebagai penerima itu layak usahanya dan penerima bersedia melunasi pengembalian angsuran pinjaman. Selanjutnya dilaksanakan penanda tanganan perjanjian antara2 pihak yang sepakat melakukan kerjasama dan mentaati isi perjanjian. Dalam perjanjian tersebut, dalam hal ini, pihak kesatu adalah UPTD Perkuatan Permodalan KUMKM, dan pihak kedua adalah penerima pinjaman menandatangani Berita Acara Penerimaan Dana Bergulir.

Sebagian besar responden menyatakan tidak ada perjanjian sanksi kredit yang dilakukan dalam penyelenggaraan penyaluran kredit dana bergulir. Demikian pula seleksi terhadap agunan tidak dilakukan. Tabel 8 menunjukkan prosentase jawaban responden mengenai perjanjian sanksi kredit dan seleksi terhadap agunan. Apabilaterjadi kredit macet, hampir $95 \%$ responden menyatakan tidak ada sanksi atau hukuman apabila mereka tidak menepati perjanjian kredit untuk melunasi angsuran pinjaman. Hanya 5\% memberikan pernyataan ada sanksi apabila pembayaran angsuran tidak dilakukan.

Tabel 8 : Perjanjian Sanksi Kredit dan Seleksi Terhadap Agunan Dalam Penyelenggaraan Kredit Dana Perkuatan Modal Usaha KUMKM Tahun 2003-2013 (dalam \%)

\begin{tabular}{|c|l|c|c|c|c|c|c|c|c|c|c|}
\hline No & \multicolumn{1}{|c|}{ Aspek } & 2003 & 2004 & 2005 & 2006 & 2007 & 2008 & 2009 & 2010 & 2011 & 2012 \\
\hline 1 & Perjanjian sanksi kredit & & & & & & & & & & \\
\hline & Ada & 2 & 5 & 9 & 7 & 8 & 10 & 6 & 5 & 8 & 7 \\
\hline & Tidak ada & 98 & 95 & 91 & 93 & 92 & 90 & 94 & 95 & 92 & 93 \\
\hline 2 & Seleksi terhadap agunan & & & & & & & & & & \\
\hline & Ada & 0 & 0 & 0 & 0 & 0 & 10 & 10 & 15 & 12 & 13 \\
\hline & TIdak ada & 100 & 100 & 100 & 100 & 100 & 90 & 90 & 85 & 88 & 87 \\
\hline
\end{tabular}

Sumber : Data Primer 


\section{5) Pencairan Kredit}

Pencairan kredit dana bergulir dilaksanakan oleh Bank Pelaksana, dalam hal ini, yaitu Bank Lampung pada cabangcabang di kabupaten/kota yang bersangkutan.Penrima pinjaman dapat mengambil pencairan kredit secara langsung dikantor Bank Lampung setempat dan selanjutnya melakukan pelunasan atau pembayaran angsuran pinjaman Bank Lampung tersebut. Mengingat masyarakat belum mengetahui prosedur pencairan dan pembayaran angsuran kredit yang harus dibayar setiap bulannya, sebelum menerima pencairan kredit, maka dinas yang membidangi Koperasi dan UMKM Kota Bandar Lampung dan petugas pada Bank Lampung seharusnya memberi penjelasan tentang hal tersebut secara jelas dan rinci. Tabel 9 menjelaskan proses pencairan kredit yang dilaksanakan oleh lembaga perbankan Bank Lampung.

Tabel 9 : Pencairan Kredit Dalam Penyelenggaraan Pinjaman Dana Perkuatan Modal Usaha KUMKM di Kota Bandar Lampung Tahun 2003 s/d 2012 (dalam \%)

\begin{tabular}{|c|l|c|c|c|c|c|}
\hline No & \multicolumn{1}{|c|}{ Aspek } & $\begin{array}{c}\text { Sangat } \\
\text { baik }\end{array}$ & Baik & Cukup & Kurang & $\begin{array}{c}\text { Sangat } \\
\text { kurang }\end{array}$ \\
\hline 1 & $\begin{array}{l}\text { Petugas membimbing tentang } \\
\text { aturan kredit }\end{array}$ & 7,8 & 50 & 21,6 & 14,7 & 5,9 \\
\hline 2 & $\begin{array}{l}\text { Prosedur pengajuan kredit sudah } \\
\text { berjalan baik }\end{array}$ & 2 & 34,3 & 42,2 & 7,8 & 13,7 \\
\hline 3 & $\begin{array}{l}\text { Petugas kredit melayani dengan } \\
\text { baik }\end{array}$ & 34,3 & 54,9 & 4,9 & 5,9 & 0 \\
\hline 4 & $\begin{array}{l}\text { Pelayanan petugas pencairan kredit } \\
\text { baik }\end{array}$ & 36,3 & 63,7 & 0 & 0 & 0 \\
\hline 5 & $\begin{array}{l}\text { petugas pencairan kredit memberi } \\
\text { jumlah uang dengan depat }\end{array}$ & 46,1 & 34,3 & 5,9 & 7,8 & 5,9 \\
\hline & Jumlah & 126,5 & 237,3 & 74,5 & 36,3 & 25,5 \\
\hline & Rata-rata & 24,3 & 47,5 & 14,9 & 7,3 & 5,1 \\
\hline
\end{tabular}

Sumber : Dana Primer

\section{6) Pelayanan Kredit}

Setelah menerima dana perkuatan modul usaha KUMKMseharusnya menerima langsung penjelasan dari Bank Pelaksana mengenai kredit dana perkuatan tersebut, mereka menjadi memahami berapa nilai angsuran yang harus dibayar setiap bulannya. Sehingga pihak penerima pinjaman dalam hal ini KUMKM dapat memahami hak dan kewajibanya terhadap dana pinjaman tersebut. Pemberian informasi yang tidak dilakukan oleh pihak perbankan menunjukkan bahwa tidak adanya suatu kerjasama penyaluran dana perkuatan modal usaha yang lebih baik.
Namun pelayanan kredit perlu ditingkatkan agar unit usaha lebih menyadari kewajibannya untuk melunasi pinjaman. Diperlukan bantuan semua pihak termasuk pihak Bank untuk mengingatkan kewajiban dan sanksi apabila mereka tidak memenuhi kewajibannya. Tabel 10 menjelaskan ada tidaknya pemotongan uang dalam pelayanan kredit.

Tabel 10 : Pelayanan kredit dalam penyelenggaraan pinjaman dana perkuatan modal usaha KUMKM di Kota Bandar Lampung Tahun 2003 s/d 2012 (dalam \%)

\begin{tabular}{|c|c|c|c|}
\hline No & Aspek & Ya & $\begin{array}{c}\text { Tida } \\
\mathrm{k}\end{array}$ \\
\hline
\end{tabular}




\begin{tabular}{|c|l|c|l|}
1 & $\begin{array}{l}\text { Petugas pencairan } \\
\text { kredit memeotong } \\
\text { atau meminta uang }\end{array}$ & 17,9 & 81,3 \\
\hline 2 & Pungutan lain & 17,9 & 81,3 \\
\hline & Jumlah & 35,8 & $\begin{array}{l}162, \\
6\end{array}$ \\
\hline & Rara-rata & 17,9 & 81,3 \\
\hline
\end{tabular}

Sumber : Data Primer

\section{7) Bimbingan dan Pembinaan}

Setelah mendapat pencairan kredit dana perkuatan modal usaha KUMM dari Bank Pelaksana, setiap penerima perlu mendapat bimbingan dan pembinaan agar pelaksanaan pencairan kredit sesuai dengan tujuan dan hasil yang diharapkan. Tugas membimbing dan membina UKM dalam kegiatan ini adalah tugas Tim Pelaksana Kegiatan atau UPTD Perkuatan Permodalan KUMKM dan dinas yang membidangi koperasi dan UKM kabupaten/kota. Tugas bimbingan dan pembinaan tersebut sebagaimana dicantumkan dalam Petunjuk Teknis (Juknis) kegiatan. Dalam Tabel 11, responden yang mendapat bimbingan baik secara langsung maupun melalui kegiatan pelatihan.

Tabel 11 : Bimbingan dan Pembinaan Dalam Penyelenggaraan Pinjaman Dana Perkuatan Modal Usaha di Kota Bandar Lmapung tahun 2003 s/d 2012

\begin{tabular}{|c|l|c|c|c|c|c|}
\hline No & \multicolumn{1}{|c|}{ Aspek } & $\begin{array}{c}\text { Sangat } \\
\text { baik }\end{array}$ & Baik & Cukup & Kurang & $\begin{array}{c}\text { Sangat } \\
\text { kurang }\end{array}$ \\
\hline 1 & $\begin{array}{l}\text { Petugas membimbing bidang } \\
\text { manajemen }\end{array}$ & 10,8 & 52 & 15,7 & 18,6 & 2,9 \\
\hline 2 & $\begin{array}{l}\text { Petugas membimbing bidang } \\
\text { pemasaran }\end{array}$ & 2,9 & 36,3 & 5,9 & 47,1 & 7,8 \\
\hline 3 & $\begin{array}{l}\text { Petugas membimbing bidang } \\
\text { produksi }\end{array}$ & 10,8 & 36,3 & 10,8 & 36,3 & 5,9 \\
\hline 4 & $\begin{array}{l}\text { Petugas membimbing bidang } \\
\text { pengembangan usaha }\end{array}$ & 7,9 & 28,4 & 10,8 & 47,1 & 5,9 \\
\hline 5 & $\begin{array}{l}\text { Petugas membina usaha tepat } \\
\text { sasaran }\end{array}$ & 2,9 & 26,5 & 42,2 & 20,6 & 7,8 \\
\hline 6 & Petugas melakukan penelitian usaha & 0 & 10,8 & 10,8 & 44,1 & 34,3 \\
\hline 7 & Petugas melakukan promisi usaha & 0 & 18,6 & 7,8 & 47,1 & 26,5 \\
\hline 8 & Petugas membimbing dan membina & 5,9 & 18,6 & 23,5 & 44,1 & 7,8 \\
\hline 9 & $\begin{array}{l}\text { Petugas memberikan perhatian } \\
\text { terhadap masalah yang dihadapi }\end{array}$ & 0 & 7,8 & 7,8 & 76,5 & 7,8 \\
\hline 10 & $\begin{array}{l}\text { Petugas memberi jalan keluar dari } \\
\text { permaslahan }\end{array}$ & 0 & 5,9 & 2,9 & 73,5 & 17,6 \\
\hline & Jumlah & 41,2 & 241,2 & 138,2 & 454,9 & 124,5 \\
\hline & Rata-rata & 4,1 & 24,1 & 13,8 & 45,5 & 12,5 \\
\hline
\end{tabular}

\section{Sumber: Data Primer}

Berdasarkan table di atas dapat dilihat bahwa pemberian bimbingan mendapat bimbingan bidang administrasi pembukuan. Terdapat $47 \%$ responden mereka menyatakan belum mendapat bimbingan bidang administrasi pembukuan secara intensif. Hal ini menimbulkan kekhawatiran penerima dana tidak melakukan pembukuan dengan baik maka akan mempengaruhi kinerja atau perputaran roda usaha mereka dan dikuatirkan adanya pengunaan modal usaha untuk keperluan konsumtif. 


\section{8) Pengawasan}

Pengawasan dilakukan oleh UPTD Perkuatan Permodalan KUMKM untuk mencegah terjadinya penyimpangan pemanfaatan dana perkuatan atau pelanggaran mekanisme penyaliran dana perkuatan modal usaha KUMKM. Langkah strategis yang ditempuh untuk mengawasi pelaksanaan kegiatan, Pelaksana Teknis Kegiatan dari UPTD perkuatan permodalan KUMKM melakukan kegiatan monitoring dan evaluasi. Kegiatan pemantauan tersebut berupa melakukan pengawasan secara langsung. Tim monitoring mendatangi rumah-rumah penerima program dan bertemu langsung dengan penerima pinjaman.

Berdasarkan Tabel 12, pengawasan terhadap pemberian pinjaman dana perkuatan modal usaha KUMKM adalah kurang baik. UPTD Perkuatan PermodalanKUMKM tidak pernah mendatangi penerima pinjaman dan

Tabel 12 : Pengawasan Dalam Penyelenggaraan Pinjaman Dana Perkuatan Modal Usaha KUMKM di Kota Bandar Lampung tahun 2003 s/d 2012

\begin{tabular}{|c|l|c|c|c|c|c|}
\hline No & \multicolumn{1}{|c|}{ Aspek } & $\begin{array}{c}\text { Sangat } \\
\text { baik }\end{array}$ & Baik & Cukup & Kurang & $\begin{array}{c}\text { Sangat } \\
\text { kurang }\end{array}$ \\
\hline 1 & Petugas memonitoring dana usaha & 0 & 34,3 & 7,8 & 45,1 & 12,7 \\
\hline 2 & Petugas mengevaluasi usaha & 0 & 7,8 & 28,4 & 52,9 & 10,8 \\
\hline 3 & $\begin{array}{l}\text { Sistem pengawasan sudah berjalan } \\
\text { dengan baik }\end{array}$ & 2,9 & 18,6 & 15,7 & 50 & 12,7 \\
\hline 4 & $\begin{array}{l}\text { Petugas teratur mengunjungi } \\
\text { kegiatan usaha }\end{array}$ & 0 & 10,8 & 2,9 & 60,8 & 25,5 \\
\hline 5 & $\begin{array}{l}\text { Petugas memmbahas permasalahan } \\
\text { yang dihadapi }\end{array}$ & 0 & 2,9 & 7,8 & 63,7 & 25,5 \\
\hline 6 & $\begin{array}{l}\text { Apabila menunggak dapat } \\
\text { bermusyawarah dengan petugas }\end{array}$ & 0 & 18,6 & 0 & 70,6 & 10,8 \\
\hline & Jumlah & 2,9 & 93,2 & 62,7 & 343,1 & 98 \\
\hline & Rata-rata & 0,5 & 15,5 & 10,5 & 57,2 & 16,3 \\
\hline
\end{tabular}

Sumber : Dana Primer

Hasil monitoring dan evaluasi yang dilakukan secara baik dan terus menerus dapat merupakan bahan masukan untuk memantau perkembangan usaha para penerima pinjaman. Aspek pengawasan yang dilakukan UPTD Perkuatan Permodalan KUMKM tidak dilaksanakan sebagai bagian dari tanggung jawab agar tidak terjadi kemacetan pembayaran atau terjadi penyimpangan/kelalaian para pihak dalam pelaksanaan. Tingginya tunggakan pengembalian angsuran yang terjadi merupakan indikasi bahwa dana yang diberikan pemerintah tersebut, dianggap sebagai hibah belaka, terdistorsi oleh bantuan-bantuan pemerintah lainnya. Apabila kegiatan monitoring dan evaluasi dilakukan dengan baik, tunggakan atau kredit macet dapat dicegah dan di kurangi. Penunggak angsuran semestinya dapat didatangi oleh Pelaksana. Kegiatan, selanjutnya melakukan musyawarah untuk mengetahui penyebab mereka tidak membayar angsuran dan selanjutnya membahas permasalah yang dihadapi dan mencari alternatif pemecahannya. 
dilakukan dengan baik dapat mencegah lebih dini kemungkinan penyimpangan, sehingga kegiatan yang dibiayai dari anggaran pemerintah tidak mengalami kerugian bagi Negara dan menghilangkan atau mengurangi manfaat positif yang sebenarnya bisa diperoleh dari kegiatan tersebut. Pengawasan yang baik dapat mengoptimalkan penggunaan kredit dan dapat menimbulkan rasa tanggung jawab untuk memanfaatkan bantuan pemerintah dan melunasi pinjaman secara disiplin

\section{9) Penggunaan Perkuatan Modal Usaha KUMKM}

Penggunaan dana perkuatan modal usaha KUMKM dimanfaatkan penerima dana untuk memperkuat permodalan, menciptakan lapangan kerja dan meningkatkan kapasitas usaha. Penggunaan dana perkuatan modal usaha KUMKM secara efektif dan optimal dapat meningkatkan pendapatan dan taraf hidup masyarakat untuk itu, bagi unit usaha KUMKM yang telah memperoleh pinjaman dana perkuatan modal usaha KUMKM dapat memanfaatkan dana yang disediakan untuk kelangsungan dan pengembangan usaha yang sudah mereka rintis sebelumnya. Tabel 13 menunjukkan sikap responden terhadap kegunaan pinjaman dana perkuatan modal usaha KUMKM tersebut dan hasil pemberian pinjaman terhadap kelangsungan usaha.

Tabel 13 : Penggunaan dana perkuatan modal usaha dalam penyenggaraan pinjaman bagi KUMKM di Kota Bandar Lampung tahun 2003 s/d 2012 (dalam \%)

\begin{tabular}{|c|l|c|c|c|c|c|}
\hline No & \multicolumn{1}{|c|}{ Aspek } & $\begin{array}{c}\text { Sangat } \\
\text { baik }\end{array}$ & Baik & Cukup & Kurang & $\begin{array}{c}\text { Sangat } \\
\text { kurang }\end{array}$ \\
\hline 1 & $\begin{array}{l}\text { Dana dipengaruhi untuk } \\
\text { mengembangkan usaha }\end{array}$ & 44,1 & 52,9 & 0 & 0 & 2,9 \\
\hline 2 & $\begin{array}{l}\text { Kondisi perkembangan usaha } \\
\text { setelah mendapatkan dana bergulir }\end{array}$ & 0 & 21,6 & 28,4 & 18,6 & 31,4 \\
\hline 3 & $\begin{array}{l}\text { Dana bergulir dapat digunakan } \\
\text { untuk kegiatan usaha lain }\end{array}$ & 0 & 0 & 7,8 & 5,9 & 86,3 \\
\hline 4 & $\begin{array}{l}\text { Dana bergulir yang diterima dapat } \\
\text { meningkatkan kerja usaha }\end{array}$ & 0 & 17,6 & 21,6 & 7,8 & 52,9 \\
\hline 5 & $\begin{array}{l}\text { Dana bergulir dapat memperkuat } \\
\text { modal usaha }\end{array}$ & 2,9 & 36,3 & 15,7 & 5,9 & 39,2 \\
\hline & Jumlah & 47,1 & 128,4 & 73,5 & 38,2 & 212,7 \\
\hline & Rata-rata & 9,4 & 25,7 & 14,7 & 7,6 & 42,5 \\
\hline
\end{tabular}

Sumber : Dana Primer

Berdasarkan wawancara mendalam, penyebab kegagalan UKM penerima dana perkuatan modal usaha KUMKM dalam meningkatkan usahanya antara lain :(2) Persaingan usaha dimana pelaku usaha KUMKM kalah bersaing dengan industriatau pengusaha bermodal besar, (2) Rendahnya produksi dan kualitas produk mengakibatkan tidak ada penmintaanbarang dan jasa, (3) Harga bahan-bahan baku mengalami kenaikan, (4) Adanya kenaikan harga Bahan Bakar Minyak (BBM), terutama minyak tanah dan bensin, dll. Kegagalan usaha membuat pelaku usaha tidak lagi membayar angsuran cicilannya. Dampak lanjutan adalah tidak lancarnya perguliran dana kegiatan tersebut sehingga mengurangi kesempatan bagi unit usaha lain 
untuk memperoleh dana pinjaman modal serupa.

\section{0) Tanggungjawab}

Aspek tanggungjawab dan kesadaran penerima kredit dana perkuatan modal usaha untuk memanfaatkan dana pinjaman sebaik mungkin untuk mengembangkan usaha, mengembalikan pinjaman secara mengangsur, dan sebagainya adalah baik.Tanggung jawab dan kesadaran tersebut merupakan kemampuan kognisi pelaku usaha yang menyadari pentingnya memanfaatkan dana tersebut untuk pengembangan usaha dan mengembalikan pinjaman agar dapat memberi kesempatan bagi orang lain memperoleh akses permodalan seperti yang lainnya. Namun data pengembalian pinjaman yang menunjukkan tingginya tunggakan pengembalian angsuran dana perkuatan modal usaha merupakan fakta yang berbicara lain. Antara kesadaran kognisi akan manfaat penggunaan dana perkuatan modal usaha, berbeda dengan sikap dan perilaku mereka yang tidak mekmasi pinjaman adalah merupakan hal yang bertolak belakang. Masalah kredit macet merupakan kenyataan atau fakta dari perilaku KUMKM yang terjadi di lapangan yang tidak bisa dielakkan.

UPTD Perkuatan Permidalan

KUMKM Dinas Koperasi, UMKM Perindustrian dan Perdagangan Provinsi
Lampung sebagian instansi pemerintah daerah yang bertanggung jawab terhadap kemajuan pelaksanaan program perkuatan permodalan, menurut pelaku usaha, turut bertanggung jawab terhadap perkembangan usaha yang mereka jalankan, Sebagai instansi yang menjadi leading sector dalam kegiatan pinjaman dana perkuatan modal usaha KUMKM, maka UPTD Perkuatan Permodalan KUMKM memiliki kepentingan terhadap keberhasilan usaha KUMKM. Apabila program perkuatan modal ini berjalan lancar, maka kinerja UPTD Perkuatan Permodalan KUMKM menjadi baik, dan apabila tidak berjalan seabagaimana mestinya, maka kinerja instansi pemerintah tersebut menjadi buruk. Tabel 14 menunjukkan sikap responden bahwa tugas pokok dan fungsi UPTD Perkuatan Permodalan KUMKM adalah terus memantau dan mengawasi kelancaran pelaksanaan program perkuatan permodalan tersebut. UPTD Perkuatan Permodalan KUMKM bertanggung jawab untuk menata mekanisme penyaluran pinjaman dana bergulir agar supaya berjalan lancar dan berhasil dan mencapai tujuan dan sasaran kegiatan yang diharapkan. Penggunaan dana APBD sebaik mungkin merupakan kewajiban yang harus dilakukan UPTD Perkuatan Permodalan KUMKM sebagai tuntutan good governance pemerintah daerah kepada masyarakat Provinsi Lampung secara keseluruhan.

Tabel 14 : Tanggung Jawab Pengguna Dana Perkuatan Modal Usaha Dalam Penyelenggaraan Dana Perkuatan di Kota Bandar Lampung tahun 2003 s/d 2012

\begin{tabular}{|c|l|l|l|l|l|l|}
\hline No & \multicolumn{1}{|c|}{ Aspek } & $\begin{array}{c}\text { Sangat } \\
\text { baik }\end{array}$ & \multicolumn{1}{|c|}{ Baik } & Cukup & Kurang & $\begin{array}{l}\text { Sangat } \\
\text { kurang }\end{array}$ \\
\hline & $\begin{array}{l}\text { Membuka dan memberi kesempatan } \\
\text { bagi usaha ekonomi lemah untuk } \\
\text { meningkatkan taraf hidup }\end{array}$ & 6,9 & 39,2 & 23,5 & 17,6 & 12,7 \\
\hline 2 & Menciptakan lapangan kerja & 10,8 & 39,2 & 21,6 & 22,5 & 5,9 \\
\hline 3 & $\begin{array}{l}\text { Mengembangkan kehidupan } \\
\text { ekonomi }\end{array}$ & 2,9 & 47,1 & 28,4 & 18,6 & 2,9 \\
\hline
\end{tabular}




\begin{tabular}{|l|l|l|l|l|l|l|} 
& $\begin{array}{l}\text { Meningkatkan dan menghidupkan } \\
\text { ekonomi }\end{array}$ & 5,9 & 42,2 & 23,5 & 25,5 & 2,9 \\
\hline 5 & Memperkuat aspek permodalan & 5,9 & 23,5 & 34,3 & 36,3 & 0 \\
\hline & Jumlah & 32,4 & 191,2 & 131,4 & 131,4 & 24,5 \\
\hline & Rata-rata & 6,5 & 38,2 & 26,3 & 24,1 & 4,9 \\
\hline
\end{tabular}

Sumber : Dana Primer

\section{1) Manfaat Dana Bergulir}

Sesuai tujuan dan sasaran pelaksanaan kegiatan pinjaman dana perkuatan modal usaha adalah untuk meningkatkan permodalan dan pengembangan usaha, maka manfaat yang diperoleh dari dana bergulir merupakan peluang bagi pelaku usaha untuk meningkatkan taraf hidup dan menciptakan lapangan pekerjaan. Selain itu, manfaatdana perkuatan modal usaha dapat mengembangkan kehidupan ekonomi masyarakatdan memperkuat permodalan pelaku usaha.Berdasarkan Tabel 15 diketahui bahwa pelaku usaha mengetahui bahwa mereka dapat memanfaatkan pinjaman dana perkuatan modal usaha dengan baik. Penerima kredit juga menyadari bahwa mereka harus mengelola manajemen usaha secara lebih baik sehingga pergerakan dana usaha terus meningkat karena adanya bantuan perkuatan permodalan. Namun pengetahuan mengenai manfaat dana perkuatan modal usaha tidak sesuai dengan realita yang mereka alami. Tidak semua pelaku usaha setuju dengan manfaat dana perkuatan modal usaha yang mereka terima karena ternyata dalam realita sebenarnya, dana pinjaman tersebut tidak mengakibatkan peningkatan usaha, peningkatan taraf hidup dan kehidupan ekonomi masyarakat, ketidak mampuan mengelola usaha, kenaikan harga-harga bahan baku dan transportasi merupakan kendala dalam upaya mengembangkan usahanya. Apa yang dicita-citakan semula, ternyata tidak terwujud dalam kenyataan.

Tabel 15 : Manfaat Dana Perkuatan Modal Usaha Dalam Penyelenggaraan Dana Perkuatan di Kota Bandar Lampung tahun 2003 s/d 2012 (dalam \%)

\begin{tabular}{|c|l|l|l|l|l|l|}
\hline No & \multicolumn{1}{|c|}{ Aspek } & $\begin{array}{c}\text { Sangat } \\
\text { baik }\end{array}$ & \multicolumn{1}{|c|}{ Baik } & Cukup & Kurang & $\begin{array}{l}\text { Sangat } \\
\text { kurang }\end{array}$ \\
\hline 1 & $\begin{array}{l}\text { Membuka dan memberi kesempatan } \\
\text { bagi usaha ekonomi lemah untuk } \\
\text { meningkatkan taraf hidup }\end{array}$ & 6,9 & 39,2 & 23,5 & 17,6 & 12,7 \\
\hline 2 & Menciptakan lapangan kerja & 10,8 & 39,2 & 21,6 & 22,5 & 5,9 \\
\hline 3 & $\begin{array}{l}\text { Mengembangkan kehidupan } \\
\text { ekonomi }\end{array}$ & 2,9 & 47,1 & 28,4 & 18,6 & 2,9 \\
\hline 4 & $\begin{array}{l}\text { Meningkatkan dan menghidupkan } \\
\text { ekonomi }\end{array}$ & 5,9 & 42,2 & 23,5 & 25,5 & 2,9 \\
\hline 5 & Memperkuat aspek permodalan & 5,9 & 23,5 & 34,3 & 36,3 & 0 \\
\hline & Jumlah & 32,4 & 191,2 & 131,4 & 131,4 & 24,5 \\
\hline & Rata-rata & 6,5 & 38,2 & 26,3 & 24,1 & 4,9 \\
\hline
\end{tabular}

Sumber : Dana Primer

Pelaksanaan kegiatan pinjaman dana perkuatan modal usaha tahun $2003 \mathrm{~s} / \mathrm{d} 2012$ memiliki beberapa kelemahan terutama pada tahapan input dan proses. Padatahapan input, diketahui bahwa nilai pinjaman menunjukkan bahwa besaran plafon 
pinjaman tidak didasarkan proses identifikasi kebutuhan modal KUMKM dimiliki.Tidak ada penetapan nilai pinjaman sebagai standar pinjaman sehingga bisa diukurtingkat keberhasilan program. Salah satu indikator keberhasilan program dana perkuatan modal usaha KUMKM adalah lancarnya pengembalian pinjaman (tidak kurang dari $80 \%$ ) dan terjadinya peningkatan kesejahteraan masyarakat sekitar (Teguh, 2008). Untuk mendukung keberhasilan tersebut, kegiatan pendampingan dan bimbingan intensif pada penerima kredit harus dilakukan.

Dari wawancara mendalam dengan Pelaksana kegiatan, diketahui bahwa mereka tidak pernah memiliki data keberhasilan kegiatan dana perkuatan modal usaha KUMKM sehingga sulit mengukur tingkat keberhasilan program perkuatan permodalan tersebut. Untuk tahapan proses, menunjukkan kelemahan pada kegiatan bimbingan dan pembinaan serta pengawasan. Penerima kredit menyatakan bahwa selama masa pinjaman kredit, baik secara kualitas maupun frekuensi pertemuan dengan UPTD Perkuatan Permodalan KUMKM, sangat rendah.Hal itu menyebabkan : (1) Tidak memiliki saluran atau forum konsultasi apabila mengalami masalah dalam pengembangan usahanya, (2) Tidak memiliki kesadaran dan tanggung jawab untuk mengembalikan pinjaman tepat waktu.

Kelemahan pelaksanaan kegiatan dana perkuatan modal usahatahun2006 s/d2012 melahirkan hasil yang cukup baik, dimana tunggakan pengembalian pinjaman sebesar $45 \%$. Artinya, dana perguliran yang semestinya dapat diterimaoleh KUMKM lainnya pada periode berikutnya, mengalami hambatan. Prinsip perguliran tidak berjalan sebagaimana prinsip dan tujuan kegiatan itu sendiri.

\section{b. Pembahasan}

Setelah melakukan analisis terhadap proses pelaksanaanpinjaman dana perkuatan modal usaha KUMKM, selanjutnya dilakukan analisis hubungan antar variabelvariabel di atas untuk mempertajam hasil penelitian.Setiap tahapan yang dilaksanakan diduga memiliki keterkaitan satu samalain. Kegiatan sosialisasi sebagai langkah awal pelaksanaan kegiatan perlu dilakukan sebaik mungkin agar supaya penerima kredit memahami tujuan dan sasaran program, Sosialisasi yang efektif niscaya dapat menghasilkan produktivitas dans perkuatan modal usaha KUMKM bagi peningkatan usaha penerima. Demikian pula variabel seleksi kelayakan usaha harus dilakukan secara cermat, agar penerima pinjaman adalah KUMKM yang benar-benar membutuhkan bantuan permodalan dan siap memanfaatkan dana perkuatan modal usaha KUMKM untuk mengembangkan usahanya serta memiliki tanggung jawab untuk, mengembalikan pinjaman. Untuk itu dilakukan pengujian statistik deskriptif tabulasi silang (crosstab) menggunakan sofware SPSS versi 16 terhadap aspek sosialisasi, seleksi kelayakan usaha, bimbingan dan pembinaan, pengawasan, tanggung jawab mengembalikan pinjaman. Hasil pengujian tabulasi silang di atas menunjukkan beberapa hal, yaitu:

1) Aspek seleksi kelayakan usaha memiliki hubungan dengan tanggung jawab penerima kredit untuk mengembalikan pinjaman dan memanfaatkan dan perkuatan modal usaha KUMKM untuk mengembangkan usaha.

2) Aspek bimbingan dan pembinaan usaha diyakini responden memiliki hubungan dengan pengawasan terhadap usaha, Apabila bimbingan dan pembinaan dilaksanakan maka sekaligus penerima pinjaman mendapat pengawasan selama pemanfaatan danaperkuatan modal usaha KUMKM yang diterima. 
3) Aspek seleksi kelayakan usaha memiliki hubungan dengan aspek pengembangan usaha, Penerima pinjaman yang telah diseleksi dengan baik dan benar sesuai kriteria dan persyaratan dapat berhasil mengembangkan usaha. Unit usaha tersebut dipastikan memang memiliki kecenderungan potensi menjadi unit usaha yang sukses meningkatkan usaha dan pendapatan.

4) Dampak program terhadap peningkatan pendapatan diuji hubungannya dengan variabel seleksi kelayakan usaha dengan bimbingan dan pembinaan. Hasilnya menunjukkan pendapatan penerima dana perkuatan modal usaha KUMKM dapat meningkat apabila seleksi kelayakan usaha dilakukan secara baik dan benar sebagai mana kriteria dan persyaratan kelayakan usaha. Artinya, responden memahami bahwa terjadinya kenaikan tingkat pendapatan KUMKM penerima karena seleksi yang dilakukan dengan baik dan benar serta memenuhi kriteria dan persyaratan untuk menerima kredit. Adanya pengungkit berupa bantuan permodalan, seharusnya sudah dapat menaikkan tingkat pendapatan usaha penerima pinjaman. Hal tersebut karena sebelumnya si penerima pinjaman dana perkuatan modal usaha KUMKM sudah memiliki usaha yang bersifat mandiri, produktivitas lancar dan sudah melakukan penjualan ke luar wilayahnya.

Aspek-aspek lainnya seperti aspek sosialisasi tidak memiliki hubungan dengan pengembalian angsuran, pengembangan usaha seleksi kelayakan usaha. Demikian pula aspek peningkatan pendapatan dengan seleksi kelayakan usaha, diyakini responden tidak memiliki hubungan. Hasil uji tabulasi silang ini menunjukkan beberapa faktor yang mempengaruhi keberhasilan pelaksanaan kegiatan dana perkuatan modal usahaKUMKM yang dirasakan penerima pinjaman. Proses seleksi yang baik akan menentukan siapa penerima pinjaman yang bertanggung jawab mengembalikan pinjaman. Demikian pula bimbingan dan pembinaan yang baik sekaligus pula berfungsi sebagai upaya mengawasi penggunaan dana pinjaman.

Penyaluran kredit dana perkuatan modal usaha KUMKM dimaksudkan dapat meningkatkan pendapatan pelaku usaha. Setelah menerima pinjaman diharapkan usaha KUMKM berkembang menghasilkan output peningkatan pendapatan dan penyerapan tenaga kerja. Apabila pendapatan pelaku usaha setelah menerima bantun permodalan mengalami peningkatan atau kebih besar dari tingkat daya beli, maka terdapat peningkatan pendapatan pelaku usaha setelah menerima pinjaman. Demikian pula sebaliknya. Tidak semua penerima kredit berhasil memanfaatkan dana perkuatan sehingga pendapatannya meningkat. Ada sebagian kecil penerima kredit gagal memanfaatkan bantuan permodalan untuk meningkatkan usaha, pinjaman tersebut habis dikonsumsi untuk memenuhi kebutuhan sehari-hari atau habis modal karena usahanya mengalami kegagalan.

Maka dari hasil penelitian dapat diketahui bahwa strategi penyaluran dana perkuatan modal usaha KUMKM oleh UPTD Perkuatan Permodalan KUMKM yang meliputi kegiatan sosialisasi, seleksi kelayakan usaha, bimbingan dan pembinaan dan pengawasan maka pemberian pinjaman dana perkuatan tepat sasaran sehingga program penyaluran dana perkuatan modal usaha KUMKM yang dilaksanakan oleh UPTD Perkuatan Permodalan KUMKM dapat meningkatkan pendapatan usaha KUMKM penerima pinjaman.

Berdasarkan hasil pembahasan di atas hipotesis yang diajukan dapat terbukti, ini 
berarti strategi pengembangan pinjaman dana perkuatan modal oleh UPTD Perkuatan Permodalan KUMKM dengan tepat sasaran berpengaruh pada peningkatan perekonomian KUMKN.

\section{KESIMPULAN DAN SARAN}

\section{A. Kesimpulan}

Program pola perkuatan dana perkuatan modal usaha KUMKM melalui pola perguliran pada dasarnya adalah suatu upaya kelembagaan yang dilakukan oleh pemerintah dalam rangka meningkatkan kinerja usaha Kopersai dan UMKM. Dalam kerangka yang lebih luas, program ini diharapkan menjadi inisiasi dan pemicu untuk mengembangkan perekonomian wilayah melalui aktivitas ekonomi produktif sesuai dengan keunggulan komparatif dan kompetitif wilayah bersangkutan. Penelitian ini berusaha mengevaluasi kinerja pengelola kegiatan, dalam hal ini UPTD Perkutan Permodalan KUMKM dalam mengelola kegiatan pinjaman dana perkuatan modal usaha KUMKM. Merujuk siklus manajemen pengelolaan dana perkuatan maka hasil evaluasi terhadap kinerja penyelenggaraan pinjaman dana perkuatan modal usaha KUMKM disampaikan di bawah ini.

Pertama, efektivitas program belum memenuhi tingkat ketercapaian tujuan, ataumemenuhi kebutuhan atau masalah sosial ekonomi yang dihadapi KUMKM penerimakredit, baik dalam arti ketepatan pencapaian output, maupun pencapaian outcome.Besaran pinjaman yang disalurkan kepada KUMKM hampir sama rata nilainya, tanpamelalui pengujian mendalam berapa sebenarnya bantuan modal yang dibutuhkan masing-masing KUMKM.

Kedua, efisiensi atau rasio antara output atau outcome dengan biaya yangdikeluarkan, yaitu dana APBD yang dialokasikan pada tahun 2003, 2004 dan
2006 jumlahnya semakin mengecil. Hal ini dikarenakan besarnya tunggakan para peminjam sehingga perguliran dana tersebut tidak berjalan lancar dan berimbang.

Ketiga, relevansi program pinjaman dana perkuatan modal usaha KUMKMtelah sesuai dongan tujuan, kebutuhan, atau masalah sosial ekonomi yang dihadapi. HalIni sejalan dengan tujuan kegiatan pinjaman dana perkuatan modal usaha KUMKM berupaya antara lain : a) Mengembangkan dukungan permodalan usaha KUMKM untuk mengembangkan usahanya namun belum tersedia pembiayaan secara memadai dari lembaga keuangan yang ada; b) Menggalang partisipasi berbagai pihak dalam pengembangan basis permodalan KUMKM. Relevansi kegiatan Ini sangat erat dengan visi dan misi UPTD Perkuatan Permodalan KUMKM tahun 2009-2014.

Keempat, secara keekonomian (economy), pelbagai input yang dibutuhkan dalam program pinjaman dana perkuatan modal usaha KUMKM, dalam hal ini UPTD Perkuatan Permodalan KUMKM diperoleh dengan harga yang wajar dan dengan kualitas yang memadai. Hanya saja, hasil akhir berupa tingginya tunggakan mengurangi kondisi kualitas hasil akhirnya.

Kelima, keberlanjutan dari hasil yang dicapai yaitu apakah dapat mencapai kebutuhan masyarakat (sosial ekonomi) secara berkelanjutan. Hasil penelitian menunjukkan belum terjadi proses keberlanjutan melalui peningkatan pendapatan dan penyerapan tenaga kerja yang signifikan sebagai penanda peningkatan kesejahteraanmasyarakat. Efektivitas keberhasilan dan keberlanjutan upaya pemberdayaan masyarakat dengan menggunakan instrumen dana perkuatan modal usaha KUMKM belum cukup. Pertama efektivitas pendampingan 
kelompok belum maksimal dilakukan UPTD Perkuatan Permodalan KUMKM dan lembaga-lembaga terkait lainnya.: dan Kedua, kesiapan lembaga pelayanan (dalam hal ini Bank Lampung) belum melakukan perannya sebagai konsultan teknis yang secara intensif menjadi mitra usaha KUMKM.

\section{B. Saran}

Dari analisis dan kesimpulan yang diuraikan di atas, maka dapat disarankan halhal sebagai berikut :

1. Pemerintah Provinsi Lampung melalui UPTD Perkuatan Permodalan KUMKM perlu melanjutkan program perkuatan modal usaha KUMKM yang bersifat bergulir (revolving). Hal ini mengingat tingginya minat KUMKM yang memerlukan aksespermodalan usaha dan potensi peluang usaha KUMKM yang ada. InvestasiPemerintah Provinsi Lampung dalam program kredit mikro menunjukkankeberpihakan Pemerintah daerah terhadap upaya menghilangkan

kelemahanstruktural dan kultural KUMKM di Provinsi Lampung.

2. UPTD Perkuatan Permodalan KUMKM perlu meningkatkan koordinasi dan sinergisitas antar program di tingkat Kabupaten/Kota melalui pertemuan rutin yang melibatkan dinas/instansi terkait, pihak swasta maupun organisasi kemasyarakatan. Diharapkan partisipasi seluruh stake holder menjadi pengungkit keberhasilan program peningkatan akses pembiayaan KUMKM.

3. Untuk mengatasi tingginya tunggakan pinjaman dana perkuatan modal usaha KUMKM, maka
UPTD Perkuatan Permodalan dapat mengadakan pembinaan yang lebih intensif kepada KUMKM yang mengalami permasalahan usaha sehingga menyebabkan tidak dapat mambayar angsursn pinjaman. Selain pemberiaan pembinaan yanag lebih intensif UPTD Perkuatan Permodalan KUMKM dapat mengadakan kerjasama pendampingan penyelesaian pinjaman bermasalah melalui lembaga hukum secara berkelanjutan dalam rangka untuk mengamankan asset pemerintah daerah.

4. Perlu dipikirkan untuk membuat alternatif kegiatan dari program peningkatan akses pembiayaan KUMKM, selain melakukan kegiatan pemberian pinjaman dana perkuatan modal usaha KUMKM. Seperti melakukan kegiatan memberi subsidi bunga pada lembaga perbankan yang menyediakan kredit mikro bagi KUMKM.

\section{DAFTAR PUSTAKA}

AhmadNd, (2003), Strategi Bertahan Industri Kecil, Ekonomi dan Bisnis, Vol.9No.2,Juni 2007,hal.127-146

Andang, (2002), Masalah Pengembangan UKM di Indonesia, Sebuah Upaya Mencari Jalan Alternatif, Makalah, diakses dari http://www kadimindonesia.or id.

Arikunto, Suharsimi, 2004, Prosedur Penelitian Suatu Pendekatan Praktik. Rineka Cipta Jakarta

Diskop. UMKM dan Indag Provinsi Lampung, (2009), Rencana Sratejik Dinas Koperasi UMKM dan Indag 
Provinsi Lampung Tahum 2009 2914,Lampung.

Dwiwinarno, (2008), Masalah dan Dinamika Usaha Kecil, Jurnal Ekonomi, Vol. 12 No. 01 Maret 2007, hal. 64 - 77

Dibyo, Prabowo (2011), Perkembangan Industri Skala Kecil di Indonesia, Jakarta: PT Mutiara Sumber Widya.

Iman dan Adi, (2009), Usaha Kecil Sebagai Strategi Pembangunan Ekonomi : Berkaca Dari Pengalaman Taiwan, dalam Jurnal Analisis Sosial Vohume 9 No. 2 Agustus 2009.

Joko dan Sri, (2006), Masalah dan Kinerja Industri Kecil, Jurnal Akuntansi Bisnis dan Manajemen, Vol. 15 No. 2, Agustus 2008, hal. 271 - 280

Kementrian Koperasi dan UKM, (2010), Rencana Stratejik Kementrian Koperasi dan UKM Tahun 2010 2014, Jakarta.

Mariah, 2008, Analisis Dampak Krisis Moneter Terhadap Kinerja UKM di Subsektor Industri Pengolah Hasil Hutan, Kajian Ekonomi dan Keuangan, Tahun IV No.3

Peraturan Pemerintah Nomor 53, 2010, Disiplin Pegawai Negeri Sipil. Jakarta : Badan Administrasi Kepegawaian Nasional.

Semeru, Lembaga Penelitian (2003), Masalah dan Kinerja Industri Kecil, Jurnal Riset Ekonomi dan Manajemen, Vol. 8 No. 2, Mei 2003, hal. 188 199

Sutrisno dan Sri, (2000), Economic Development, Sevent Edition, Massachusetts
Sutrisno Hadi, (1992), Metodologi Research, Fakultas Psikologi, Yogyakarta, hal 21

Tambunan, Tulus (2002), Perkembangan UKM dalam Era AFTA: Peluang, Tantangan, Permasalahan dan Alternatif Solusinya. Paper Diskusi pada Yayasan indonesia Forum

UU No. 20 Tahun 2008 Tentang Usaha Mikro, Kecil dan Menengah www.depkop.go.id 